\title{
COMENTARIOS CRÍTICOS A LA SUBORDINACIÓN DE CRÉDITOS EN LAS ACCIONES REVOCATORIAS CONCURSALES ${ }^{*}$
}

\author{
Miguel ÁNGel Alarcón CAÑUTA**
}

RESUMEN: En el presente trabajo se exponen algunas implicancias que en torno a la certeza jurídica de los acreedores y el incentivo a la contratación presenta el efecto de la subordinación de créditos que la nueva regulación de las acciones revocatorias concursales exhibe en la Ley No 20.720. Como sanción, requiere el estudio de sus fundamentos y un análisis de sus requisitos de procedencia, de manera tal de evaluar las consecuencias que la normativa presenta para un grupo no menor de acreedores que contrata, o pretende contratar, con un deudor persona jurídica, futuro deudor concursado.

PALABRAS CLAVE: Subordinación de créditos; acciones revocatorias concursales; revocabilidad objetiva; revocabilidad subjetiva; mala fe

\section{CRITICAL COMMENTS TO THE SUBORDINATION OF CREDITS IN REVOCATORY BANKRUPTCY ACTIONS}

ABSTRACT: This paper exposes some implications of the legal certainty of creditors, related to the effect that the subordination of credits in the new regulation of revocatory bankruptcy actions in Chilean Law $\mathrm{N}^{\circ}$ 20.720, has as an incentive to contracting. As a sanction, it requires a study of its basis and an analysis of the requirements of its legal provenance, in order to analyze the consequences that the regulation represents to a not so small group of creditors who contract, or pretend to contract, with a legal person debtor, future bankrupt debtor.

\footnotetext{
* $\quad$ Fecha de recepción: 18 de abril de 2016.

Fecha de aceptación: 15 de septiembre de 2016.

** Docente e Investigador de la Universidad Arturo Prat, Sede Victoria (Chile). Licenciado en Ciencias Jurídicas Universidad Católica de Temuco, Chile. Mg. en Derecho con Especialidad en Derecho Privado, Universidad de Barcelona, España. Correo electrónico: mialarco@ unap.cl
} 
KEY WORDS: Subordination of credits; bankruptcy revocatory actions; objective revocability; subjective revocability; bad faith

Sumario: Introducción. 1) Naturaleza jurídica y fundamento de la subordinación del artículo 292 de la Ley $N^{o}$ 20.720. (1.1.) El perjuicio a la masa de acreedores y su influencia en el fundamento de la subordinación de créditos en la revocabilidad objetiva. (1.2.) La mala fe como fundamento de la subordinación del crédito del artículo 292 de la Ley No 20.720. 2) La mala fe del acreedor en la subordinación del crédito en la revocabilidad subjetiva. (2.1.) Mal estado de los negocios del deudor y subordinación del crédito del acreedor. 3) Necesidad de una reforma a modo de conclusión. Bibliografía citada.

\section{INTRODUCCIÓN}

Uno de los principios clásicos ${ }^{1}$, que trasciende al sistema concursal moderno y actualizado por la Ley No 20.720, de 10 de octubre de 2014, de reorganización y liquidación de empresas y personas (Ley), es el de la par conditio creditorum, a saber, la protección de los intereses de los acreedores ante la situación patrimonial desfalleciente del deudor concursado, en cuanto dar satisfacción a sus acreencias mediante la distribución coordinada y proporcional ${ }^{2}$ del producto de la realización de los bienes bajo una ley de igualdad ${ }^{3}$. Para ello, la Ley establece una serie de mecanismos e instituciones concursales que buscan hacer efectivo este principio. Para lo que nos interesa, tomaremos en cuenta una que aunque con identidad jurídica ${ }^{4}$ y orígenes en el régimen común ${ }^{5}$, presenta una regulación

1 SAndoval López, Eduardo (2014) Reorganización y liquidación de empresas y personas. Derecho concursal. $7^{\text {a }}$ edición actualizada. Santiago: Editorial Jurídica de Chile, p. 37.

2 Importante es destacar la postura de Goldenberg Serrano, Juan Luis (2010) "Consideraciones críticas respecto al denominado principio de la par conditio creditorum". Revista Chilena de Derecho, Vol. 37, No 1, p. 80, para quien la par conditio creditorum no sería un principio, sino más bien una regla de distribución proporcional.

3 Gómez, Rafael y Eyzaguirre, Gonzalo (2010) El derecho de quiebras. Santiago: Editorial Jurídica de Chile, p. 27; Sandoval (2014) 37. Goldenberg (2010) 79 - 80, argumenta en torno a la errónea consideración tradicional de la par conditio creditorum como una manifestación patente de la igualdad formal.

4 Puga Vial, Juan (2014) Derecho concursal. Del procedimiento concursal de liquidación. Ley 20.720. 4a edición actualizada. Santiago: Editorial Jurídica de Chile, pp. 442 y 443.

5 Quetglas, Rafael Sebastián (2013) Concurso y rescisión. Valencia: Editorial Tirant lo Blanch, p. 27, expresa que la postura dominante es la de entender que no hace falta una categoría especial de acción rescisoria, ya que, como él señala debe considerarse que las acciones rescisorias concursales participan de la naturaleza de las acciones rescisorias comunes, 
propia y especial ${ }^{6}$ en el derecho concursal, circunscribiéndose de manera específica en la protección de los intereses de los acreedores ${ }^{7}$, y en fin, de la par conditio creditorum $^{8}$. Es la institución de las acciones revocatorias concursales.

Conceptualizadas en términos generales como mecanismos jurídicos que el legislador establece para dejar sin efecto o restar eficacia a ciertos y especiales actos o contratos ejecutados o celebrados por una empresa deudora o persona deudora durante una época anterior al inicio del procedimiento concursal ${ }^{9}$, las acciones revocatorias concursales encuentran su fundamento en la protección de la par conditio creditorum $^{10}$. Se pretende con ellas el respeto de los intereses de los acreedores coordinados por el sistema concursal ${ }^{11}$; intereses que giran en torno a la justicia distributiva que debe reinar en la repartición del haber del deudor insolvente ${ }^{12}$.

Las acciones revocatorias concursales son reguladas, para las personas jurídicas o empresas deudoras, en los artículos 287 y 288 de la Ley. Tales disposiciones contemplan, respectivamente, las llamadas acción revocatoria concursal objetiva y acción revocatoria concursal subjetiva. La diferencia que presentan una respecto de la otra estriba en sus requisitos de procedencia ${ }^{13}$, donde si bien para ambas es necesario que se haya celebrado entre deudor persona jurídica y acreedor ciertos actos o contratos dentro de un tiempo específico anterior a la fecha de apertura del concurso, para la acción revocatoria objetiva solo será necesario que tales actos hayan producido un perjuicio a la masa, mientras que para la subjetiva, además de este perjuicio, será requisito que el acreedor haya conocido el mal estado de los negocios del deudor, esto es, se encuentre de mala fe ${ }^{14}$.

aunque adaptadas a las particulares exigencias cuya utilización en el procedimiento concursal lo requiere.

6 Quetglas (2013) 30 y 31, establece que el sistema de rescisión concursal no es autónomo del sistema común, pues las diferencias, que entre uno y otro existen, obedecen a la naturaleza del procedimiento concursal, el cual está dotado de una mayor facilidad probatoria.

7 Quetglas (2013) 33, señala que el fundamento jurídico de las acciones rescisorias es la protección de los acreedores.

8 Sandoval (2014) 38 y 39, expresa que las acciones revocatorias concursales favorecen a la masa o conjunto de acreedores, por cuanto tendrán mayores posibilidades de ser satisfechas sus acreencias.

9 Sandoval (2014) 261.

10 Gómez/Eyzaguirre (2010) 25.

11 Goldenberg (2010) 83, citando a Finch (2002) 7, señala que el procedimiento concursal busca resolver en una sola instancia los conflictos patrimoniales del deudor, no necesariamente brindando un tratamiento igualitario a los acreedores, sino que coordinando sus intereses del modo que el legislador haya estimado económica y socialmente más adecuado. Puga (2014) 437.

Sandoval (2014) 267; Puga (2014) 431.

Historia de la Ley No 20.720, p. 13. 
Tomando en cuenta el afán protector de los intereses de los acreedores en función de la protección de la par conditio creditorum, nuestra Ley, en términos muy similares a lo expuesto en la Ley Concursal española, ha establecido en el inciso segundo del artículo 292 un nuevo y especial efecto para las acciones revocatorias concursales. La norma en comento, de manera muy escueta, expresa que "La parte condenada [por la sentencia motivada por una acción revocatoria concursal] deberá restituir efectivamente la cosa a la masa y tendrá derecho a la devolución de lo que hubiere pagado con ocasión del acto o contrato revocado, debiendo verificar ese monto en el Procedimiento Concursal respectivo, quedando pospuesto el pago hasta que se paguen integramente los créditos de los acreedores valistas".

La norma viene a establecer una nueva categoría de crédito pospuesto o subordinado ${ }^{15}$, que tiene su origen en los efectos que tal disposición presenta respecto de las acciones revocatorias concursales. En términos simples, acogida la revocación del acto o contrato celebrado entre un acreedor y el deudor, se subordinará el crédito que se origine en beneficio del acreedor con ocasión de la revocación del acto o contrato respectivo, y que dice relación con la prestación que eventualmente debiere serle devuelta por el efecto principal de la revocación, a saber, la restitución de las prestaciones efectuadas entre las partes.

Ahora bien, atendida la casi inadvertible redacción de la norma, el efecto subordinativo a simple vista parece no tener mayor trascendencia, e incluso pareciere ser acorde con el espíritu protector de los intereses de los acreedores de la Ley. Sin embargo, al tomar en consideración la consecuencia jurídica que el precepto contiene, nos preguntamos si desde el punto de vista de los acreedores sujetos pasivos de las acciones revocatorias concursales, contendrá la Ley un tratamiento protector igual al común de los acreedores.

En efecto, desde el punto de vista de la certeza jurídica, la subordinación que como efecto presentan las acciones revocatorias concursales, importa una clara obligación de poner atención en la contratación entre acreedor y deudor, futuro concursado. La misma ataca específicamente los intereses de los acreedores, que habiendo contratado con el deudor, o pretendiendo contratar con él, lo hacen en especiales circunstancias que podrían implicar que en el futuro sus créditos eventualmente sean pos-

15 Goldenberg Serrano, Juan Luis (2015) "Los créditos legalmente pospuestos en la Ley 20.720". Revista de Derecho de la Universidad Austral de Chile, Vol. XXVIII, No 2, diciembre, p. 103 . 
puestos $^{16}$ al último lugar del orden de prelación de créditos, donde con gran probabilidad de forma alguna podrán verlos satisfechos, aunque sea en parte ${ }^{17}$. Llama la atención, en este sentido, que la Ley establezca que la subordinación se efectuará "a un lugar posterior al de los acreedores valistas", con lo que se pone de manifiesto un severo tratamiento a los titulares de dichos créditos, toda vez que la norma estaría estableciendo una sexta categoría de créditos, posteriores a la quinta de los quirografarios o valistas $^{18}$.

Si bien es cierto existe doctrina en torno al tratamiento de las acciones revocatorias concursales, se ha podido advertir que a pesar de la incorporación del efecto subordinativo en la nueva Ley, no existe una reflexión en torno a los alcances que tal efecto presentaría para los intereses de los acreedores, y que a su vez podría repercutir en la contratación actual y futura con un deudor persona jurídica. Desde este punto de vista, la pregunta que guía el presente trabajo es la siguiente: ¿presenta nuestra Ley concursal una regulación coincidente con el respeto de los intereses de todos los acreedores concursales, incluso aquellos que han sido sujeto pasivo en una acción revocatoria concursal?, o en otros términos ¿qué implicancias prácticas y jurídicas tendrá la regulación del nuevo efecto subordinativo de las acciones revocatorias concursales para los intereses de cierto grupo de acreedores que ha contratado, o pretende contratar, con una persona jurídica, futura deudora concursada?

En el presente trabajo se intenta dar cuenta de las implicancias que, sobre la certeza jurídica de los acreedores y la contratación, presenta el efecto subordinativo que la Ley concursal patria establece para la revocación de los actos o contratos celebrados con un deudor persona jurídica en virtud de los artículos 287 y 288.

16 A este respeto, Goldenberg (2015) 110, se refiere al carácter debilitado de los créditos subordinados o pospuestos en el procedimiento concursal. Respecto de ellos, en p. 112 expresa que "[...] serán todos los titulares de créditos no subordinados lo que recibirán los beneficios de la posposición legal, aumentando sus posibilidades de cobro", por lo que contrario sensu, podemos decir que los titulares de créditos subordinados tendrán pocas posibilidades de pago.

17 Ferré Falcón, Juan (2006) Los créditos subordinados. 1a edición. Navarra: Editorial Thomson Civitas, p. 166.

18 Interesante en este sentido es lo señalado por Goldenberg (2015) 104, cita 71, al dar cuenta de lo expresado por Ugarte Godoy. J.J. "Sobre la posibilidad de pactar que una obligación tenga el carácter de subordinada en el Derecho chileno", en Varas Braun, J.A. y Turner Saelzer, S. (coords.): Estudios de Derecho Civil, LexisNexis, Santiago, 2005, p. 387 (la referencia bibliográfica es del autor). Expresa que Ugarte Godoy "había advertido que la subordinación (aunque se refiere a la posposición voluntaria, previo a la reforma de la Ley 20.190) implicaba una suerte de preferencia para los acreedores de la quinta clase, creando una especie de sexta clase, lo que solo podría haber sido establecido por el legislador". 
Para ordenar la exposición, en un primer apartado se estudia someramente la naturaleza jurídica de esta especial forma de posposición de créditos; lo cual es necesario si se pretende efectuar un análisis interpretativo posterior.

En la segunda parte, se determina el fundamento de la subordinación de créditos que presenta la acción revocatoria concursal objetiva, desde el punto de vista de la injerencia que el requisito de perjuicio a la masa tiene en tal determinación. A su vez, estableciéndose el sentido y alcance de la expresión perjuicio a la masa en función del fundamento de la subordinación, se analiza de qué forma la interpretación del requisito influye en la posposición de los créditos originados en beneficio del acreedor al momento de operar la revocación objetiva de los actos que el artículo 287 especifica; y consecuentemente, se describen las implicancias que tiene la regulación de la revocación objetiva en los intereses de los acreedores que pretendan contratar con el deudor, futuro concursado.

En el plano de la acción revocatoria subjetiva, en la tercera parte de este trabajo se da cuenta del contenido del fundamento de la subordinación de créditos en función de los requisitos que la acción presenta. Se discute además en torno a la necesidad de contemplarse en la norma del artículo 288 el requisito del conocimiento por parte del acreedor del mal estado de los negocios del deudor, al tomarse en consideración las implicancias prácticas y de prueba relacionadas con la certeza jurídica, que este requisito presentaría para los intereses de los acreedores que pretendan contratar con el deudor, futura empresa concursada.

Finalmente, a modo de conclusión, y a la luz de las falencias que en el plano regulatorio queden en evidencia, se establecen ciertas apreciaciones que tienen como propósito aportar en la evolución del tratamiento de la normativa, buscando una conjugación adecuada entre la preocupación por los intereses de todos los acreedores concursales, la buena fe y el fomento de la contratación con el deudor.

\section{1) NATURALEZA JURÍDiCA Y FUNDAMENTO DE LA SUBORDINACIÓN DEL ARTÍCULO 292 DE LA LEY No 20.720}

El artículo 292 de la Ley, en su inciso segundo, establece que la parte que haya sido condenada a la restitución de la cosa a la masa activa con ocasión de una acción revocatoria concursal, verá pospuesto su crédito correspondiente a la devolución de lo que hubiere pagado, a un lugar posterior al de los acreedores valistas. La Ley establece una nueva categoría de 
crédito subordinado ${ }^{19}$, que procede de los efectos que el artículo 292 presenta respecto de las acciones revocatorias concursales, y que a su turno se encuentran reguladas en los artículos 287 y 288.

Haciendo una comparación con el tratamiento de esta institución en otros ordenamientos, la Ley 22/2003 de 9 de julio, Concursal espańola (LCE), en torno a las acciones rescisorias concursales, establece por un lado que aun sin existir mala fe se rescindirán los contratos que causen un perjuicio a la masa ${ }^{20}$, y por otro, subordina los créditos del acreedor de mala fe que se originen de la rescisión de los actos o contratos que haya celebrado $^{21}$ con el deudor. Es claro que para la rescisión del artículo 71.1 de la Ley Concursal española no se requiere la existencia de mala $\mathrm{fe}^{22}$, pero sí para la subordinación del crédito del acreedor que contrató con el deudor (futuro concursado) dentro de los dos años anteriores a la declaración de concurso. De acuerdo a ello, en la Ley Concursal española el fundamento de la sanción de subordinación se encuentra en la mala fe del acreedor que contrató con el deudor.

Pero en la Ley patria no se aprecia claramente lo anterior, toda vez que si bien por un lado el artículo 287 consagra la acción revocatoria concursal objetiva, esto es, sin requerir la mala fe del acreedor del deudor concursado, por otro, y para la subordinación de su crédito, no expresa si

19 Goldenberg (2015) 103.

20 Guillón, Antonio (2005) "La acción rescisoria concursal”. En Acedo, José et al:: Estudios sobre la Ley Concursal. Libro Homenaje a Manuel Olivencia. Madrid: Editorial Marcial Pons, tomo IV, p. 4126, expresa que la Ley Concursal española se inspiró en la normativa del Código Civil español al regular la acción rescisoria concursal, "pero sin recoger un requisito que la jurisprudencia del Tribunal Supremo ha exigido siempre que concurra: el consilium fraudis, bien entendido, de manera amplia, como conciencia del deudor del perjuicio que causa al acreedor con su acto, bien como actividad intencionada o dolosa".

21 El artículo 71 Ley Concursal española señala: "Acciones de reintegración".

"1. Declarado el concurso, serán rescindibles los actos perjudiciales para la masa activa realizados por el deudor dentro de los dos años anteriores a la fecha de la declaración, aunque no hubiere existido intención fraudulenta".

Por su parte, el artículo $92.6^{\circ}$ del mismo cuerpo normativo señala:

"Créditos subordinados".

"Son créditos subordinados":

"... $\sigma^{\circ}$ Los créditos que como consecuencia de rescisión concursal resulten a favor de quien en la sentencia haya sido declarado parte de mala fe en el acto impugnado...”. GArcía SANZ, Arturo (2005) "Notas sobre el sistema de reintegración de la masa en la nueva Ley Concursal”. En Acedo, José et al.: Estudios sobre la Ley Concursal. Libro Homenaje a Manuel Olivencia. Madrid: Editorial Marcial Pons, tomo IV, p. 4080, expresa que "Si se prueba la mala fe, el demandado debera devolver los bienes o derechos para reintegrarlos a la masa activa. Su actuación de mala fe determina que su derecho a la restitución de la prestación realizada no se califique como crédito contra la masa sino como un crédito subordinado [...]".

22 Escribano Gámir, Rosario (2005) "La reintegración de la masa activa del concurso". En Acedo, José et al.: Estudios sobre la Ley Concursal. Libro Homenaje a Manuel Olivencia. Madrid: Editorial Marcial Pons, tomo IV, p. 4042. 
requiere que se encuentre o no de mala fe. Recordemos que en este caso la posposición del crédito es una consecuencia inmediata y automática ${ }^{23}$ de la revocación del acto o contrato celebrado por el acreedor en virtud del artículo 292.

Tal situación nos lleva a preguntarnos si para la Ley nacional, a pesar de no señalarlo expresamente, ¿es necesaria la mala fe del acreedor para subordinar el crédito que en su beneficio se origina al producirse la revocación de los actos o contratos en los términos de los artículos 287 y 288?, o desde otro ángulo, ¿cuál es el fundamento, en nuestra legislación, que determina que en todo caso sea subordinado el crédito del acreedor respecto de quien ha operado la acción revocatoria concursal?

De acuerdo a la doctrina extranjera y mayoritaria ${ }^{24}$, la subordinación del crédito a la cual hacemos referencia es una sanción ${ }^{25}$ que encuentra su fundamento en el hecho de que respecto del acreedor que contrata con el deudor se ha determinado su mala fe con ocasión del ejercicio de las acciones rescisorias concursales.

Siguiendo a la doctrina comparada, debemos estimar que tras la revocación del acto, es atendido a un criterio sancionador que el artículo 292 releva el crédito del acreedor ${ }^{26}$; especialmente si tomamos en consideración los supuestos de procedencia de las acciones revocatorias concursales como base previa de la subordinación, esto es, el perjuicio causado a

23 En este sentido, Goldenberg (2015) 106.

24 En este sentido Ferré (2006) 315; Alemany, Jesús (2004) "Subordinación contractual y subordinación concursal”. Revista española de doctrina, jurisprudencia y bibliografía, No 2, p. 1886; Garrido, José María (2004) “La subordinación de créditos”. En Rojo, Angel y Beltrán, Emilio (Directores): Comentario de la Ley Concursal. Editorial Thomson Civitas, tomo I, p. 1668, expresa que "Este supuesto de subordinación tiene una finalidad sancionatoria. De hecho, el crédito descrito no es solo subordinado, sino que es "subordinado entre los subordinados". La posición crediticia del sujeto que ha obrado de mala fe, y cuya actuación hubiere provocado un daño a los acreedores del deudor común, debe ser colocada en el último lugar de la graduación de acreedores"; Alonso Ledesma, Carmen (2004) "Comentarios”. En Pulgar Ezquerra, Juana; Alonso Ureba, Alberto; Alonso Ledesma, Carmen y Alcover Grau, Guillermo (Directores): Comentarios a la legislación concursal. Editorial Dikinson, tomo I, p. 930. Por su parte, Veiga Copo, Abel (2006) "Los créditos subordinados en la Ley Concursal”. Revista de Derecho Bancario y Bursátil, No 102, abril-junio, p. 17, señala que para algunos casos supone una sanción, pero en este contexto "debería apreciarse en su verdadera dimensión toda conducta fraudulenta y lasciva...”.

25 En tal sentido Ferré (2006) 315, al referirse a los créditos subordinaos que se originan de las acciones rescisorias concursales al existir mala fe de parte del acreedor; LiNACERO DE LA Fuente, María (2005) Las acciones de reintegración en la Ley Concursal. Espańa: Editorial Reus, pp. 264 - 267.

26 En este sentido se manifestó el profesor Juan Esteban Puga Vial ante la Comisión de Constitución de la Cámara de Diputados, en segundo trámite constitucional, del Proyecto de Ley que sustituyó el régimen concursal vigente por una ley de reorganización y liquidación de empresas y personas, como se aprecia en la Historia de la LeY No 20.720, Informe de Comisión de Constitución, p. 201. 
la masa activa, y el conocimiento por parte del acreedor del mal estado de los negocios del deudor. De otra forma no se entendería una consecuencia o efecto más desfavorable para los acreedores que contratan con el deudor respecto de quienes ya se ha revocado un acto o contrato. Además, en este sentido se ha pronunciado una actualizada doctrina en nuestro país, al estimar que tras la subordinación de créditos en aplicación de las acciones revocatorias concursales existe un criterio sancionador ${ }^{27}$.

Pero si lo anterior es así, ¿̨cuál es el fundamento de la sanción en el derecho nacional?, ¿por qué sancionar a todo acreedor respecto de quien ya se ha revocado un acto o contrato celebrado con el deudor concursado?

Antes de responder a esta interrogante es necesario señalar que la misma se plantea solo en los casos del artículo 287 de la Ley, pues de acuerdo a lo establecido por el artículo 288, los casos de revocabilidad subjetiva se fundamentan en el conocimiento del mal estado de los negocios que el acreedor contratante tenía respecto del deudor. Ello nos insta necesariamente a hablar de mala fe del acreedor que contrata con el deudor, futuro concursado, a quien con posterioridad le será además subordinado el crédito correspondiente a las devoluciones y restituciones que por efecto tiene la revocación concursal -volveremos sobre esto más adelante-.

\section{(1.1.) El PERJUICIO A LA MASA DE ACREEDORES Y SU INFLUENCIA EN EL FUNDAMENTO DE LA SUBORDINACIÓN DE CRÉDITOS EN LA REVOCABILIDAD OBJETIVA}

Para contestar la interrogante planteada en el acápite anterior pongamos como fuente de comparación al derecho español y su Ley Concursal.

En el artículo 73 de la mencionada Ley se expresa que se subordinarán los créditos de los acreedores de mala fe, y no de todos aquellos que contraten con el deudor. El fundamento de tal sanción, en este caso, es la mala fe del acreedor.

El artículo 292 de nuestra Ley no establece en su enunciado normativo el fundamento de la sanción de subordinación, no obstante, al analizar el artículo 287 podemos inferirlo. Tal norma establece una lista de ac-

27 Es así que Goldenberg (2015) 103, expresa que los elementos, llamémoslos nosotros, requisitos de procedencia de la acciones revocatorias objetiva y subjetiva son, a saber y respectivamente, el perjuicio a la masa de acreedores y el conocimiento del mal estado de los negocios, “[...] configurarán un reproche a la conducta y justificarán, no solo la revocación del acto en cuestión, sino también el carácter pospuesto del acreedor al intentar recobrar su crédito en la masa concursal”. 
tos, a nuestro juicio taxativos ${ }^{28}$ atendido el tenor de la disposición ${ }^{29}$, que en caso de celebrarse entre acreedor y deudor (futuro concursado) dentro del plazo de un año anterior al inicio del procedimiento concursal de reorganización o de liquidación, serán revocados. Esto, expresa la norma, salvo que el acreedor o deudor acrediten que con tales actos o contratos no se hubiese causado perjuicio a la masa de acreedores.

Por otro lado, de acuerdo a lo establecido en el artículo 287 en relación al artículo 292 de la Ley, tales actos, además de configurarse como presupuesto de la revocación, siempre que hayan sido celebrados dentro del ańo anterior al inicio del concurso, se constituyen también en antecedentes de la sanción de subordinación de los créditos que se originan para el acreedor una vez haya operado la revocación. De lo señalado nos preguntamos, ¿qué hace que estos actos tengan como consecuencia de forma automática ${ }^{30}$ la subordinación de los créditos que de los efectos de tal revocación se originan para el acreedor contratante?

La interrogante la podemos resolver si solucionamos antes dos cuestiones que son necesarias para nuestra argumentación. Primero, debemos resolver la cuestión en torno al significado que en la norma presenta la frase "perjuicio para la masa de los acreedores". Esto, debido a que la disposición establece la necesidad de acreditar que tales actos no causaron tal perjuicio para posibilitar la exoneración del acreedor, tanto de la revocación del acto o contrato, como de la subordinación de los créditos que de los efectos de aquella se originan ${ }^{31}$. Siendo esto así, solo en caso que no se acredite tal supuesto, estaremos en presencia de perjuicio a la masa de acreedores. En segundo lugar, y como consecuencia inmediata de lo anterior, debemos preguntarnos si existirá algún caso en que los actos señalados en el artículo 287 no produzcan perjuicio a la masa de acreedo-

28 En este mismo sentido Contreras Strauch, Osvaldo (2010) Insolvencia y quiebra. Santiago: Editorial Jurídica de Chile, p. 201.

29 La norma señala que tales actos son "[... 1) Todo pago anticipado, cualquiera fuere la forma en que haya tenido lugar. Se entiende que la Empresa Deudora anticipa el pago también cuando descuenta efectos de comercio o facturas a su cargo y cuando lo realiza renunciando al plazo estipulado en su favor".

"2) Todo pago de deudas vencidas que no sea ejecutado en la forma estipulada en la convención. La dación en pago de efectos de comercio equivale al pago en dinero.

“3) Toda hipoteca, prenda o anticresis constituida sobre bienes del deudor para asegurar obligaciones anteriormente contraídas.[...]".

30 Goldenberg (2015) 106.

31 Puga (2014) 439, establece que en la base de toda revocación está el perjuicio que el acto irroga a los acreedores, refiriéndose al fundamento de las acciones revocatorias concursales; señalando posteriormente que "...la exigencia de conocimiento del mal estado de los negocios se inscribe en un principio más general de nuestro ordenamiento jurídico, que es la protección de la buena fe". 
res, pues solo en este caso cabrá la posibilidad de la exoneración para el acreedor.

Respecto de la expresión "perjuicio para la masa de acreedores", ni en la legislación nacional ni en la comparada existe una precisión terminológica, o si se quiere un concepto, que permita determinar sus alcances ${ }^{32}$. ¿Qué alcances debemos entender contiene la expresión en la norma? La necesidad de conocer tales alcances por parte del acreedor que contrata, o pudiere contratar, con el deudor, dice relación con la consecuencia que para él significaría la revocación del acto o contrato, que como vimos, se traduce en la subordinación automática a un lugar posterior al de los acreedores valistas, del crédito que en su beneficio se origina.

Pues bien, si entendemos la masa activa como el conjunto de bienes y derechos que forman parte del patrimonio de la persona concursada ${ }^{33}$, diremos que todo acto que haga experimentar un detrimento al mismo, importará un perjuicio para la masa activa ${ }^{34}$.

En este sentido, y en materia de derecho comparado, la doctrina ha señalado que el perjuicio patrimonial al que se refiere la Ley Concursal espańola en el artículo 71 es coincidente con toda disminución del patrimonio del deudor que no se contrapesa con una correspondiente adquisición $^{35}$, o bien, un desplazamiento de bienes o derechos del concursado a favor de terceros que disminuya su patrimonio sin justificación objetiva desde un punto de vista jurídico-económico, atendidas su causa, su contexto y sus consecuencias sobre la composición de la masa patrimonial sujeta a responsabilidad concursal ${ }^{36}$. Por su parte, la Sentencia del Tribunal

32 Guillón (2005) 4125.

33 En este sentido se pronuncia Espigares Huete, José Carlos (2011) La acción rescisoria concursal. Pamplona: Editorial Thomson Reuters, p. 97, al expresar que "la referencia a la masa activa del concurso debe identificarse, como mínimo, con el patrimonio del deudor. Así hay que entender el precepto legal. La masa activa está constituida exclusivamente por los bienes y derechos de carácter patrimonial del deudor concursado. El propio legislador lo establece en su art. $76 \mathrm{LC}$ al referirse al principio de universalidad que preside esta materia [...] -en realidad y en rigor- el art. 71.1 LC no contempla un perjuicio a la masa activa, sino un perjuicio "al patrimonio del deudor que, una vez declarado el concurso, integrará dicha masa", con este perjuicio patrimonial, claro resulta, deberá ser finalmente un perjuicio para los acreedores"; Martínez Reyes, María de los Ángeles (2012) "El perjuicio como fundamento de la acción rescisoria concursal". Revista de Derecho Concursal y Paraconcursal, No 12, p. 169; Rojo, Ángel (2004) “Comentarios”. En Campuzano, Ana Belén (Coordinadora): Comentarios a la Ley Concursal. Madrid: Editorial Thomson Civitas, tomo II, p. 1307.

34 En este sentido, Massaguer, José (2014) "La rescisión concursal. Aspectos sustantivos". En Quetglas, Rafael y Veiga Copo, Abel (Directores): Problemas actuales del concurso de acreedores. Navarra: Editorial Thomson Reuters, p. 194, señala que el perjuicio relevante a efectos de las acciones rescisorias concursales, si bien es de naturaleza patrimonial, tiene que ver con la integridad de los créditos del conjunto de los acreedores.

35 Guillón (2005) 4127.

36 Massaguer (2014) 195. 
Supremo español No 7265/2012, en relación a la rescisión concursal de pagos realizados por el concursado antes de la declaración del concurso, expresa que el perjuicio para la masa activa está determinado por una disminución de los bienes o derechos que conforman la masa que no se encuentra justificada ${ }^{37}$, pues de estarlo, no deberíamos entender un perjuicio $^{38}$.

En tal sentido se estaría pronunciando el artículo 71.2 de la LCE al seńalar que el perjuicio patrimonial se presume, sin expresar que es el perjuicio de la masa activa el que se presume ${ }^{39}$. Creemos que con ello se refiere al patrimonio del deudor contratante, quien antes de la declaración de concurso celebra algún acto especificado en la norma ${ }^{40}$. Y es claro que nos referimos y ponemos atención al patrimonio del deudor concursado al momento de contratar ${ }^{41}$, esto es antes del concurso, pues será este patrimonio el que a futuro configurará la masa activa del concurso.

37 Tribunal Supremo de España. 26 de octubre de 2012. 7265/2012, fundamento jurídico quinto, expresa que el perjuicio para la masa activa es "un sacrificio patrimonial injustificado, en cuanto que tiene que suponer una disminución de valor del activo sobre el que más tarde, una vez declarado el concurso, se constituirá la masa activa (art. 76), y, además, debe carecer de justificación".

38 En tal sentido se pronuncia Pérez Benítez, Jacinto (2012) "Créditos subordinados tras la reforma de la ley Concursal operada por la Ley 38/2011, de 10 de octubre”. En Prendes, P. y Muñoz Paredes, A. (directores): Tratado Judicial de la insolvencia. Editorial Cizur Menor, tomo II, p. 157, al hablar del perjuicio para la masa activa, al decir que "hoy se habla más claramente de "sacrificio patrimonial injustificado", hallazgo de la muy citada sentencia de la AP de Barcelona, sección 15a , de 6 de febrero de 2009, sobre la base de un anterior pronunciamiento del Tribunal Supremo, seguida en numerosas resoluciones provinciales y consagrado en las sentencias del Tribunal Supremo de 12 de abril de 2012 y 8 de noviembre de 2012". Aznar Giner, Eduardo (2013) La acción rescisoria concursal. Doctrina, jurisprudencia y formularios. Valencia: Editorial Tirant lo Blanch, p. 145, expresa que si bien la postura amplia de concepto de perjuicio es la que prima, avanza la idea de sacrificio patrimonial injustificado, postura a la cual se adhiere (p. 149 de su obra). SANCho Gargallo, Ignacio (2012) "Las acciones de reintegración”. En Prendes Carril, Pedro y Muñoz Paredes, Alfonso (directores): Tratado judicial de la insolvencia. Navarra: Editorial Aranzadi, tomo I, pp. 1146-1147.

39 En este sentido Massaguer (2014) 198.

40 Aznar (2012) 150, expresa que "No cabe identificar a los acreedores con perjuicio para la masa activa. La LC, con el sistema de reintegración previsto, atiende al interés de los acreedores concursales pero no de forma directa o inmediata..."

"Esto es, se logra una protección refleja del interés de los acreedores concursales que se hace realidad mediante la tutela del alcance cuantitativo y cualitativo del patrimonio del deudor llamado a constituirse en masa activa del concurso"; Martínez (2012) p. 178 expresa que "Aunar, por un lado perjuicio patrimonial y perjuicio a los acreedores es incorrecto. Es cierto que todo perjuicio patrimonial conlleva perjuicio para a los acreedores, pero no toda acción perjudicial para los acreedores, debe corresponderse con la existencia de una alteración económica de la masa activa que la disminuya de valor”, reiterando la idea en p. 180.

EsPigares (2011) 98, expresa que el perjuicio ha de haberse producido al momento de la realización del acto. 
Con ello en mente, podemos decir que el perjuicio para la masa activa, en principio, estará dado o configurado por el detrimento injustificado del patrimonio del deudor, ocasionado por actos que no tienen utilidad, o no son necesarios, desde un punto de vista jurídico-económico, para el beneficio o integridad ${ }^{42}$ del patrimonio del deudor; entendiéndose beneficio como aumento del activo, o disminución del pasivo ${ }^{43}$, e integridad, como mantención de su calidad ${ }^{44}$ o composición ${ }^{45}$. Se aprecia que toda disminución injustificada que sufra el patrimonio del deudor importará en efecto un perjuicio para la masa de acreedores, toda vez que como vimos, los intereses de estos giran en torno a la garantía que representa el patrimonio del deudor ${ }^{46}$, en función de las expectativas de satisfacción de sus créditos ${ }^{47}$.

Sin perjuicio de lo anterior y además, entendiéndose que la par conditio creditorum, sea como principio ${ }^{48}$, sea como regla de distribución

42 Massaguer (2014) 194.

43 Si bien en otros términos a los señalados, Espigares (2011) 152, a nuestro entender, también estaría queriendo determinar el alcance de la "disminución de valor patrimonial injustificado", que no se encuentra alejado de lo señalado por nosotros. En efecto, el autor expresa que "Lo decisivo es, por tanto, no el hecho de contraer obligaciones (que sin duda han podido determinar el aumento actual de la masa activa del deudor), sino que los actos del deudor fuesen en su momento determinantes de un vaciamiento y empobrecimiento injustificado de su patrimonio. E inclúyase aquí no solo la posibilidad de que el acto haya supuesto una reducción del patrimonio del deudor, sino que haya impedido un incremento de ese patrimonio o que o comprometa grave e injustificadamente” Además, en p. 107 expresa que "Por lo demás, y en atención a lo visto, se concluye que el perjuicio patrimonial debe identificarse con un venir a menos, cuantitativo o cualitativo, del patrimonio del deudor".

44 García-Cruces, José (2009) "Presupuesto y finalidad de la acción de reintegración en el concurso de acreedores”. En García-Cruces, José (director): La reintegración en el concurso de acreedores. Navarra: Editorial Aranzadi, Cizur Menor, p. 55, quien seńala que "el perjuicio que requiere el ejercicio de la acción rescisoria por reintegración siempre supone un menoscabo de la masa activa, bien por implicar su aminoración cuantitativa, bien por incidir negativamente en su calidad"; MARTínez (2012) 179.

45 Massaguer (2014) 195.

46 Goldenberg (2010) 80 y 81, reconoce que los acreedores tienen igual "garantía" (las comillas son del autor), basada en la responsabilidad patrimonial del deudor, la cual si bien no significa una necesaria paridad cualitativa en el derecho a la ejecución del patrimonio, podemos inferir que sí da cuenta de la importancia de la mantención de la integridad del patrimonio del deudor para efectos de dar satisfacción a los créditos de los acreedores concursales.; Massaguer (2014) 194.

47 Massaguer (2014) 195, alude a actos que "[...] se realizan en circunstancias que entrañan un empeoramiento directo de las expectativas de cobro del conjunto de acreedores [...]”. 
proporcional $^{49}$, impone el respeto de la posición jurídica ${ }^{50}$ de los acreedores o sus intereses y derechos dispuestos en la regulación del procedimiento concursal y puesto de manifiesto en el orden de prelación de créditos que de manera coordinada establece la Ley, siempre que un acreedor pretenda evadir tal reglamentación, o si se quiere, este orden de distribución proporcional establecido en la Ley, mediante actos o contratos que posibilitando una desviación ${ }^{51}$ de parte del patrimonio del deudor lo dejen en condiciones ventajosas frente a los demás acreedores ${ }^{52}$, entenderemos que existe transgresión de sus derechos, por tanto transgresión a la par conditio creditorum, y consecuencialmente, un perjuicio a la masa de acreedores $^{53}$.

En este sentido se pronuncia parte de la doctrina española para quien, si bien existirá un denominado perjuicio directo en el detrimento injustificado del patrimonio del deudor, al analizar cierta corriente jurisprudencial que vincula al concepto de insolvencia el criterio de equilibrio contable de la empresa ${ }^{54}$, deduce la existencia de un perjuicio indirecto a la masa final del concurso cada vez que no existiendo activo suficiente

49 Goldenberg (2010) 94, expresa concluyendo, que "La proporcionalidad, en suma, constituye una respuesta legislativa al problema de la concurrencia de créditos, amparada en los beneficios económicos que resultan de su establecimiento: la expansión del riesgo de insolvencia en el mayor número de acreedores posibles y la reducción de costos de transacción y supervisión de la conducta del deudor y de los demás acreedores".

50 Massaguer (2014) 196.

51 Goldenberg (2010) 86, citando a Matray (1983) 19, da cuenta que la par conditio creditorum entendida como regla de proporcionalidad otorga a cada acreedor la seguridad de que ninguno de ellos, basado en una mayor diligencia o rapidez, desviará el activo haciéndose pagar en detrimento de los demás. "Así, constatada que sea la misma y declarada la apertura del concurso, el acreedor ordinario tiene justos motivos para pensar que su crédito será pagado -a lo menos- en la misma proporción que el resto de los acreedores ordinarios, y que ninguno de estos logrará hacer valer algún artificio para la consecución tardía de un mejor derecho de cobro en su desmedro".

52 En efecto, Goldenberg (2010) 95, termina concluyendo que si bien las partes podrían excluir la aplicación de la regla de graduación y proporcionalidad y reemplazarla por un sistema de coordinación distinto, en el que bien podrían estar incluidos la celebración de actos y contratos entre deudor y un acreedor determinado, tal actividad encontraría su única limitación en la creación de preferencias. "Y esta única restricción, a nuestro juicio, no se basa en criterios de equidad, sino en que no parece lógico que alguien diferente del legislador pueda restar valor al crédito de terceros sin concederles una contraprestación a cambio de tal "expropiación"”. En el mismo sentido, Massaguer (2014) 196, alude a "[...] actos que modifiquen indebidamente la posición de los acreedores frente a la masa activa”.

53 En este sentido, Sandoval (2014) 270; Massaguer (2014) 194 y 195.

54 De acuerdo a Palao UCEDA, Juan (2013) La insolvencia inminente y el sistema concursal preventivo. Barcelona: Editorial Bosch, p. 117, tal corriente jurisprudencial afirma que "[...] el pago de deudas, derivado de la liquidación de bienes no sujetos a una explotación, es regular siempre que exista masa patrimonial suficiente como para satisfacer todas las deudas”. Por otro lado, en p. 164 , se reafirma del equilibrio contable de la empresa como criterio más objetivo en la determinación de la insolvencia. 
para todos los acreedores, se paga a unos pocos frente a los demás, quebrantándose con ello la par conditio creditorum $^{55}$. Bajo esta corriente, y de acuerdo a un autor ${ }^{56}$, la insolvencia actual también encontraría su base en todo tipo de pagos efectuados por el deudor sin consideración al resto de los acreedores.

Por otro lado, nos parece que debe entenderse incorporada en la expresión la transgresión a la par conditio creditorum, desde que el artículo 288 de la Ley la menciona en el número dos de los requisitos de procedencia de la acción revocatoria subjetiva. En tal sentido, cabe hacer presente que esta mención fue incorporada al proyecto original -que no la contenía- por la Comisión de Constitución de la Cámara de Diputados, en segundo trámite constitucional ${ }^{57}$, tras lo indicado por el profesor Rafael Gómez Balmaceda, quien refiriéndose a los efectos de la norma, criticó la falta de comprensión del proyecto de Ley respecto del contenido y alcance de la acción revocatoria concursal, puesto que la misma, a pesar de no indicarlo en el proyecto, conlleva el resguardo de la par conditio creditorum $^{58}$.

En suma, cada vez que respecto del patrimonio del deudor exista un detrimento injustificado, o con la celebración de un acto o contrato que involucre el patrimonio del deudor se esté privilegiando los intereses de ciertos acreedores en desmedro de otros, debemos entender que existe perjuicio para la masa de acreedores, sea de forma directa, o indirecta, respectivamente.

\footnotetext{
Palao (2013) 119.

Palao (2013) 140.

Historia de la Ley No 20.720, Informe de Comisión de Constitución, p. 196.

En la Historia de la Ley No 20.720, Informe de Comisión de Constitución, p. 26, se expresa por el profesor Rafael Gómez Balmaceda la necesidad de que el régimen proteja la par conditio creditorum. Por su parte, en p. 34, expresa una crítica a la regulación de las acciones revocatorias concursales en el proyecto; regulación que considera equivocada, puesto que al contrario de lo efectuado por la antigua Ley de Quiebras, el proyecto de reforma no consideraba para la revocación concursal los casos relativos a actos que resultan ser beneficiosos a ciertos acreedores y que rompen el principio de igualdad que debe imperar en el concurso. Finalmente, en pp. 195 y 196, expresó que "la norma [del artículo 289, actual 288] hace consistir el perjuicio a la masa cuando el acto o contrato no se ajusta a las condiciones del mercado y el artículo 294 [actual 292] [...] habrá de señalar, por lo mismos, la desproporción de valor, para que en lugar de restituir el bien, el condenado pague la diferencia. Lo anterior demuestra la absoluta falta de comprensión del proyecto respecto del contenido y alcance de una acción de esta naturaleza, como quiera que toda acción revocatoria se funda en el abuso que el deudor hace de la facultad que tiene de disponer de sus bienes, para causarles un perjuicio a sus acreedores, estando en conocimiento del mal estado de sus negocios, cuyo es el juicio de reproche que lleva consigo el ejercicio de esta acción, en resguardo del derecho de prenda general, que garantiza el derecho de los acreedores".
} 
Pues bien, conociendo lo que en el artículo 287 de la Ley significa la expresión perjuicio para la masa de acreedores, la norma contiene los actos y contratos que se mencionaban en la antigua Ley de Quiebras en los artículos 74 y $76^{59}$, a saber, actos y contratos a título gratuito, pagos anticipados, pagos de deudas vencidas no ejecutados en la forma estipulada en la convención, e hipotecas, prendas y anticresis constituidas sobre bienes del fallido para asegurar obligaciones anteriormente contraídas ${ }^{60}$.

En el caso español, la norma del artículo 71.2 presume el perjuicio patrimonial $^{61}$ en la celebración de actos similares o de idéntica naturale$\mathrm{za}^{62}$ a los contemplados en el artículo 287 de nuestra Ley, por lo que en todo caso y sin excepción alguna habrá recisión concursal si tales actos fueron celebrados dentro de los dos años anteriores al inicio del concurso. Por otro lado, solo si existió mala fe por parte del acreedor que contrata con el futuro deudor concursado, su crédito se verá subordinado -volveremos sobre este último punto-.

Pero la disposición de la Ley 20.720, luego de señalar que el juez revocará los actos y contratos especificados, limitándose a constatar su concurrencia dentro del plazo de un año anterior al inicio del concurso, expresa que ello será efectivo salvo que se acredite que con su celebración no se produjo perjuicio a la masa de acreedores.

Desde este ángulo se aprecia claramente una diferencia entre la norma de la Ley Concursal española y la disposición nacional, toda vez que mientras en la primera el perjuicio se presume, en la segunda la presunción no queda del todo clara.

Ahora bien, una vez determinado lo que debemos entender como perjuicio para la masa de acreedores, es que consecuentemente surge la interrogante: ¿existirá algún caso en que los actos o contratos mencionados en el artículo 278 de la Ley, siendo celebrados lícitamente entre deudor y acreedor, no produzcan perjuicio a la masa de acreedores en los términos que ya hemos establecido?

59 Contreras (2010) 201.

60 Sandoval (2014) 263 a 265; Contador Rosales, Nelson y Palacios Vargas, Cristián (2015) Procedimientos concursales. Santiago: Editorial Thomson Reuters, pp. 291 a 294.

61 Massaguer (2015) 198; Quetglas (2013) 62.

62 Cabe hacer presente que, si bien los actos de constitución de garantías reales a favor de obligaciones preexistentes se encuentra regulado en el artículo 72.3 de la Ley Concursal española, para Massaguer (2014) 205, el carácter perjudicial de estos actos parece difícilmente refutable. Expresa que puede sorprender el hecho de que la presunción tenga carácter relativo y no absoluto, pues cuando en la celebración de estos actos no medie una modificación de los términos iniciales de la obligación garantizada, debe prevalecer su naturaleza gratuita y por ello sometida a la presunción absoluta del artículo 71.2. 
Respecto de los supuestos mencionados en el artículo 287 de la Ley, algunos autores entienden que es posible encontrar actos respecto de los cuales, habiendo sido celebrados dentro del periodo previo al inicio del concurso señalado en la norma, aún puede considerarse no ser perjudiciales para la masa de acreedores. En tal sentido los autores ${ }^{63}$ expresan que "pueden existir muchos casos de actos que pueden mirarse como objetivamente revocables, pero que finalmente no causan perjuicio a la masa sino que la beneficia, mencionando a los siguientes: pago anticipado de un crédito con una tasa muy alta, cuyo acreedor la reduce, aceptando además el pago con una condonación o remisión de parte del capital; extinción de una obligación mediante la dación en pago de un bien depreciado que ya no está en la operación normal de la Compañía o que pueda tener una morosa o difícil realización; dación en pago de cuentas por cobrar de recuperabilidad incierta; constitución de garantías para asegurar el cumplimiento de obligaciones anteriormente contraídas, cuando el acreedor aumenta sus líneas de crédito, rebajando además las tasas de interés de la obligación primitiva, etc.".

No obstante lo indicado por la doctrina aludida, analizando los casos que la norma del artículo 287 de la Ley señala desde la interpretación que venimos dando de la expresión "perjuicio a la masa de acreedores", podemos decir que, habiendo sido celebrados, causarán de todas formas un perjuicio para la masa de acreedores, toda vez que, o el patrimonio del deudor concursado se verá disminuido de manera injustificada, o la celebración del acto o contrato importará una transgresión al principio par conditio creditorum.

En efecto, respecto de los actos o contratos a título gratuito podemos decir que representan una disminución innecesaria del patrimonio del deudor y por tanto una disminución de su calidad en cuanto ser garantía de pago para los acreedores. Por su parte, los pagos anticipados no mantienen la composición del patrimonio del deudor a pesar de existir un plazo como modalidades de cumplimiento ${ }^{64}$, lo cual importa una innecesaria disminución de su calidad desde el punto de vista de los intereses de cobro de los acreedores; $y$ a su vez, representan un infundado trato privilegiado a ciertos acreedores -a quienes se efectúa el pago-, en relación al resto, lo cual determina una clara transgresión al principio par conditio creditorum $^{65}$. Respecto de las hipotecas, prendas y anticresis constituidas

\footnotetext{
Contador/Palacios (2015) 295.

SANDOVAL (2014) 263.

Sandoval (2014) 263 al expresar que "No hay duda de que el deudor con el solo hecho de efectuar pagos anticipados ha querido romper la igualdad que debe existir entre los acreedores, favoreciendo a algunos de ellos en desmedro de los demás".
} 
sobre bienes del fallido para asegurar obligaciones anteriormente contraídas, las mismas repercuten en una mejoría extemporánea ${ }^{66}$ de la situación de ciertos acreedores respecto de otros, transgrediéndose con ello el principio de igualdad de trato de los acreedores concursales ${ }^{67}$.

A su turno, el hecho que se anticipe el pago del crédito, aunque con una disminución significativa del monto adeudado, significa también otorgar un privilegio a un acreedor en desmedro del resto, puesto que en su solo beneficio salen bienes del patrimonio del deudor, en circunstancias que aún existía un plazo que le hubiese permitido cumplir su obligación. Incluso esta situación podría propiciar acuerdos entre deudor y ciertos acreedores profesionales del crédito, lo cual posibilitaría beneficiar su posición jurídica frente al resto de acreedores, pues aunque si bien no lograrían un pago total o íntegro de la deuda, sí lograrían abstraerse de las normas del procedimiento concursal traspasando la carga al resto de los acreedores concursales ${ }^{68}$. Recordamos que este pago anticipado se realiza justo en el tiempo correspondiente al periodo sospechoso de un año previo al inicio del concurso.

Por otro lado, en cuanto al ejemplo de la dación en pago con un bien depreciado o de difícil realización, o la dación en pago de cuentas de recuperabilidad incierta, debemos decir que aunque un bien determinado tenga un valor muy bajo al que originariamente tenía en el patrimonio del deudor, o ciertos créditos comprendan problemas de cobro o recuperación, de todas formas son bienes que integran el patrimonio con el cual el deudor deberá responder a sus acreedores. La salida de estos bienes del patrimonio del deudor, justo en el periodo sospechoso, en efecto importa una disminución del mismo que entrańa un empeoramiento directo de las expectativas de cobro del conjunto de acreedores ${ }^{69}$.

Finalmente, respecto de la constitución de garantías para asegurar el cumplimiento de obligaciones anteriormente contraídas, cuando el acreedor aumenta sus líneas de crédito, rebajando además las tasas de interés

66 Palao (2013) 130. Puga (2014) 464, expresa que "Estas garantías atrasadas atraen todas las dudas en cuanto a la probidad de su constitución; si la obligación no estaba respaldada por garantías reales, resulta dudoso que vengan a constituirse precisamente en el periodo sospechoso".

67 Contador/Palacios (2015) 294; Sandoval (2014) 265 expresa que "Aceptarlas equivale en el fondo a dar preferencia para el pago a ciertos acreedores cuyo créditos quedarían de esta suerte garantizados.

“[...] La diferencia de fecha entre la obligación principal y la constitución de la garantía hace presumir e ánimo de favorecer a un acreedor en perjuicio de los derechos iguales de los demás".

68 Goldenberg (2014) 95, conclusión g.

69 Massaguer (2014) 195. 
de la obligación primitiva, es fácil poder percatarnos que en el contexto en que se generan tales actos no existe necesidad alguna en orden a garantizar una obligación constituida con anterioridad, a pesar de que el acreedor rebaje sus tasas de interés y el negocio pareciere ser beneficioso al aumentar las líneas de crédito. Aunque se hayan modificado los intereses del crédito $^{70}$, la deuda sigue siendo anterior y de acuerdo al contexto en el que se celebra el acto o contrato, teniendo gran relevancia el hecho de que se constituya justo en el periodo sospechoso previo al inicio del concurso, es posible apreciar que se altera la posición jurídica de un acreedor, de forma que al abrirse el concurso, tal posición le resulta injustificadamente más favorable que la que habría ocupado si al tiempo de su realización se hubiere declarado el concurso ${ }^{71}$.

Se aprecia que la Ley estaría, por un lado, previendo y previniendo una disminución injustificada del patrimonio del deudor, que repercutiría en un perjuicio directo del resto de acreedores, al estar vinculados sus intereses a la integridad del patrimonio del deudor sobre el cual hacer efectivas sus acreencias ${ }^{72}$, y por otro, previendo y previniendo una transgresión al principio par conditio creditorum en cuanto pleno respeto de la igualdad jurídica que los acreedores han de tener en el procedimiento concursal $^{73}$, o si se quiere, el respeto de los intereses y derechos de los acreedores dispuestos en la regulación del procedimiento concursal y puesto de manifiesto en el pago proporcional de sus créditos que el orden de prelación de créditos de manera coordinada establece la Ley ${ }^{74}$.

Con todo lo señalado, y de acuerdo a lo que venimos explicando en relación al perjuicio para la masa, traducido en la disminución del patrimonio del deudor de forma injustificada o la transgresión del principio par conditio creditorum, no podemos encontrar un caso en que los actos y

70 Massaguer (2014) 205, establece que respecto de los casos de constitución de garantías reales a favor de obligaciones preexistentes, el carácter perjudicial de tales actos no parece rebatible en los casos en que no haya habido una renegociación de la deuda que comporte una modificación de las circunstancias del crédito. Palao (2013) 130, luego de dar cuenta del alcance de la expresión perjuicio indirecto a la masa, y tras establecer la importancia de la teoría del crédito, señala citando la Sentencia de la Audiencia Provincial de La Coruña, de 6 de abril de 2011, que "Constituir una garantía real sobre deudas preexistentes supone reforzar una posición del acreedor a la que él renunció al momento de contraer la deuda”.

71 Massaguer (2014) 196.

72 Entendemos que Contreras (2010) 194, considera que la ley presumiría el perjuicio en los actos y contratos a título gratuito que regulaba el artículo 74 de la antigua Ley de Quiebras, y que hoy se encuentran incorporados al artículo 287 de la actual Ley, al decir que "[...] en estos casos el perjuicio está supuesto por la ley".

73 Contreras (2010) 202 y 203, respecto de los pago anticipados y las hipotecas, prendas anticresis constituidas sobre bienes del fallido para asegurar obligaciones anteriormente contraídas, respectivamente; SANDOVAL (2014) 270.

74 Goldenberg (2010). 
contratos mencionados por el artículo 287 de la Ley -de la forma en que la ley los regula- no sean fraudulentos ${ }^{75}$. Su propia esencia encierra una actividad por medio de la cual se pretende disminuir o gravar sin provecho ni utilidad el patrimonio del deudor ${ }^{76}$, o privilegiar los intereses de ciertos acreedores en desmedro de otros ${ }^{77}$.

Así las cosas, la expresión que plantea la Ley, en orden a permitir la prueba de la falta de perjuicio a la masa para evitar la revocación -y posterior subordinación del crédito-, malamente tendría aplicación en la práctica, por ser contradictoria con la norma misma, y por carecer de sentido y fundamento lógico.

La Ley nacional, aunque no lo exprese literalmente, estaría presumiendo que los actos y contratos a los que se refiere el artículo 287 causan un perjuicio a la masa de acreedores en todo caso y sin excepción alguna, y por tanto, siempre que el acreedor contrate o celebre alguno de estos actos o contratos con el deudor -en el plazo que la deposición señala- lo verá revocado, y consecuentemente, el crédito que de los efectos de tal revocación se originare en su beneficio será automáticamente subordinado.

Es entonces donde, volviendo a la interrogante inicial de este acápite, nos preguntamos ¿por qué?, ¿por qué en todo caso verá subordinado su crédito, sin excepción alguna?, ¿existirá algún caso en que respecto del acreedor, a pesar de haber celebrado uno de los actos o contratos a los que se refiere el artículo 287 de la Ley, no sea posible subordinar su crédito?

Recordemos que de la Ley Concursal española se deduce que en caso de existir buena fe en el acreedor, su crédito no se verá subordinado, pues como sanción, la posposición se ve limitada a que el acreedor haya sido declarado de mala fe en el juicio de rescisión concursal. De acuerdo a esto, y teniendo en cuenta lo que señalábamos respecto a la redacción del artículo 287 de la Ley, podríamos preguntarnos si en nuestro caso

75 Contreras (2010) 201, establece que para los actos que enumeraba el antiguo artículo 76 de la Ley de Quiebras, contemplados hoy en el actual artículo 287 de la actual Ley, "Dada la naturaleza de estos actos, la ley los considera fraudulentos [...]”.

"La ley es más severa respecto de este tipo de actos, puesto que en algunos casos se penan como delito".

76 En este sentido, Guillón (2005) 4127, expresa que "Es patente que una disminución del patrimonio operada por el concursado a favor del tercero sin que este realice ningún sacrificio es perjudicial para aquel patrimonio; en suma, puede afirmarse que la estructura de toda adquisición gratuita lleva en sí el estigma de la perjudicialidad”.

77 Contreras (2010) 201 expresa que tales actos "[...] vulneran gravemente la igualdad que debe existir entre los acreedores, es decir, el principio de la par conditio creditorum, en un momento en que el fallido sabe que está en mala situación y que no podrá satisfacer sus deudas de forma igualitaria”. 
también lo que existe detrás de la sanción de subordinación del crédito es la mala fe del acreedor que contrata con el futuro deudor concursado, toda vez que la Ley no lo establece expresamente. De ser esto efectivo, la pregunta en torno a la posibilidad de existencia de un caso en que no sea posible subordinar el crédito a pesar de haberse originado en beneficio del acreedor al operar la revocación del artículo 287, podríamos plantearla de la siguiente manera: ¿̇ería posible la existencia de algún caso en que el acreedor se encuentre de buena fe, a pesar de haber celebrado alguno de los actos o contratos a los que se refiere el artículo 287 de la Ley, de tal manera de no ver subordinado su crédito al tiempo de operar la revocación?

\section{(1.2.) LA MALA FE COMO FUNDAMENTO DE LA SUBORDINACIÓN DEL CRÉDITO DEL ARTÍ́CULO 292 DE LA LEY No 20.720}

Creemos que a pesar de que la ley no lo exprese, tras la sanción de subordinación se encuentra como fundamento la mala fe del acreedor. Para ello debemos considerar o analizar la conducta del acreedor ${ }^{78}$ que contratando con el deudor futuro concursado, en palabras del artículo 287 de la Ley, causa un perjuicio a la masa de acreedores.

La conducta de este acreedor es claramente perniciosa para los intereses de los demás acreedores, pues se configura en una actividad con la cual el acreedor, al celebrar un acto o contrato lícito, se pasa de listo y obtiene un provecho o ventaja por sobre el resto de los acreedores del deudor. Es pues una conducta que se traduce en la celebración de un acto o contrato que ampara el ordenamiento jurídico, pero que pretende obtener una ventaja o beneficio respecto del resto de los acreedores del deudor. En este sentido, podemos describir esta situación como un caso de abuso del derecho $^{79}$.

La teoría del abuso del derecho describe precisamente la situación en la que se ejerce un derecho legítimamente consagrado en la ley, pero de manera desleal ${ }^{80}$, esto es, contrariando a la buena fe y a las buenas

78 Boetsch, Cristián (2011) La buena fe contractual. Santiago: Editorial Jurídica de Chile, p. 55 , habla de la buena fe como un patrón de conducta.

79 Para una comprensión de esta teoría, Barros Bourie, Enrique (2010) Tratado de responsabilidad extracontractual. Santiago: Editorial Jurídica de Chile, pp. 621 y sgtes. Del mismo modo, Alessandri, Arturo y Somarriva, Manuel (2011) Tratado de derecho civil. Parte preliminar y general. Santiago: Editorial Jurídica de Chile, tomo I, pp. 349 y ss.

80 Boetsch (2011) 65. Citando a Díez-Picazo (1963) 141, señala que el autor expresa que "el ejercicio de un Derecho subjetivo es contrario a la buena fe no solo cuando no se utiliza para la finalidad objetiva o función económica o social para la cual ha sido atribuido a su titular, sino también cuando se ejercita de una manera o en unas circunstancias que lo hacen desleal, según las reglas que la conciencia social impone en el tráfico jurídico [... ] Los 
costumbres. De acuerdo a esto, si del ejercicio del derecho se causa un perjuicio a los intereses de un tercero, es que tal actividad, no obstante ser amparada por el derecho, se ha puesto al servicio de la malicia, la mala $\mathrm{fe}^{81}$.

Como se aprecia, y tal como lo ha señalado la doctrina, el fundamento que a su vez origina la teoría del abuso del derecho es precisamente la protección y el respeto de la buena $\mathrm{fe}^{82}$. Lo anterior se ve refrendado si sabemos que se ha estimado que la acción pauliana o revocatoria, que podemos considerar un antecedente de la acción revocatoria concursal ${ }^{83}$, encuentra su fundamento en la teoría del abuso del derecho ${ }^{84}$.

Queda claro con lo señalado que es precisamente el respeto de la buena fe el fundamento de la sanción de subordinación a la cual hacemos referencia, y especialmente, el reproche a la mala fe del acreedor que contrata con el deudor en perjuicio de la masa de acreedores. En efecto, en la contratación entre acreedor y deudor -futuro concursado- en los casos que menciona la norma del artículo 287 de la Ley, se perjudica la par conditio creditorum, pues sea que el contrato hubiese causado sus efectos, sea que no atendidos los propios efectos de la acción revocatoria concursal, de todas formas se verá desmedrado el patrimonio del deudor toda vez que el acreedor continúa siendo tal a pesar de la acción revocatoria. En este sentido, si bien la función que cumple la revocación concursal en el derecho nacional, al igual que en el ordenamiento jurídico español lo hace la rescisión concursal, es evitar que actos que hayan sido celebrados por el deudor en perjuicio de la masa queden firmes ${ }^{85}$, al posibilitar que

derechos subjetivos han de ejercitarse siempre de buena fe. Más allá de la buena fe el acto es inadmisible y se torna antijurídico".

81 Alessandri, Arturo; Somarriva, Manuel; y Vodanovic, Antonio (1990) Derecho Civil. Parte preliminar y parte general. 5a edición. Editorial Ediar ConoSur Ltda, tomo I, p. 330.

82 Alessandri/Somarriva/Vodanovic (1990) 64 se pronuncia en este sentido, citando además a Díez-Picazo (1963) 141. Por su parte, Barros (2010) 349 y ss., vincula el abuso del derecho con la buena fe.

83 La doctrina comparada expresa que la acción rescisoria concursal se ha inspirado en el sistema común de recisión de los contratos, solo que con ciertos matices. En tal sentido, Ferré (2006) 303; Guillón (2005) 4126.

84 De acuerdo a esto, se ha señalado por Larraín Ríos, Hernán (2003) Teoría general de las obligaciones. Editorial LexisNexis, p. 290, que la acción pauliana o revocatoria tiene como fundamento la teoría del abuso del derecho, que a su vez, como lo expresa Boetsch (2011) 64, tiene su fundamento en la buena fe. Por otro lado, la doctrina comparada, Ferré (2006) lo ha determinado así al referirse a los créditos subordinados del artículo $92.6^{\circ}$ de la Ley Concursal española toda vez que en tal norma se estatuye la subordinación si ha existido mala fe por parte del acreedor. En este mismo sentido, Díez Soto, Carlos (2006) Concurrencia y prelación de créditos: teoría general. Espańa: Editorial Reus, p. 82.

85 Creemos que en este sentido se estaría refiriendo el profesor Rafael Gómez Balmaceda en la Historia de la Ley No 20.710, Informe de la Comisión de Constitución, p. 196, al estimar que la acción revocatoria se funda en el abuso de un deudor de mala fe. 
tales contratos sean ineficaces a pesar de haberse cumplido las obligaciones que de ellos emanan ${ }^{86}$, tal consecuencia no es suficiente.

De acuerdo a la primera parte del artículo 292 de la Ley, como el acreedor que contrata con el deudor sigue teniendo el carácter de tal a pesar de la revocación, tarde o temprano saldrán bienes del patrimonio del deudor para satisfacer esta acreencia; bienes que de mantenerse estables, incrementarían el patrimonio del deudor en favor de los demás acreedores. ¿De qué otra forma entonces, si no es con la subordinación del crédito de este acreedor que contrata con el futuro concursado, podríamos resguardar los intereses de los demás acreedores respecto de los cuales se ha transgredido la par conditio creditorum con el acto o contrato celebrado?

La sanción de subordinación se justifica entonces porque el acreedor contrató con el deudor pretendiendo beneficiarse a costa de los intereses del resto de los acreedores. He allí el reproche que amerita que el crédito que pudiere beneficiarle al operar la revocación concursal sea pospuesto. De no ser así, no podríamos considerar el respeto de la buena fe solo con la revocación del acto o contrato, puesto que el acreedor en todo caso, y por el hecho de ser tal, pasa a formar parte de la masa de acreedores, pudiendo cobrar su crédito junto a ellos ${ }^{87}$, obteniendo por tanto una ventaja que tiene como base una actuación fraudulenta ${ }^{88}$.

Teniendo en cuenta lo ya señalado, es importante dar ciertas luces en torno a lo que en el hecho configurará la mala fe para efectos de la subordinación del crédito originado por la revocación de un acto o contrato en virtud del artículo 287 de la Ley. Para ello, importante es aclarar previamente que de acuerdo a la doctrina la mala fe se contrapone a la buena $\mathrm{fe}^{89}$, y para lo que nos interesa, consideraremos la definición ética ${ }^{90}$ de

86 Martínez (2012) 172, expresa que "La acción rescisoria tiene como finalidad lo que ha sido común a todos los sistemas de reintegración de la masa patrimonial, la restitución de la lesión".

87 En la legislación española, el crédito que se origina en beneficio del acreedor de buena fe tras la recisión del acto o contrato se integra entre los créditos contra la masa. En tal sentido García (2005) 4080.

88 En este sentido es muy ilustrador para esta argumentación considerar los que señala AlesSANDRI/SOMARrIVA/VODANOVIC (1990) 331 y 332, al expresar en forma resumida que la teoría del abuso del derecho viene a determinar una solución a aquellos casos en que habiéndose ejercido un derecho de forma ilegítima, dañándose un interés ajeno, el mismo carece de protección. Señala "De acuerdo con otro criterio, hay abuso del derecho cada vez que su titular lo ejerce y, sin justificación legítima, daña un interés ajeno que carece de protección jurídica específica. El supuesto de carecer de protección jurídica específica es lógico, porque si existe tal protección se recurriría a ella y no a la figura del abuso del derecho”, tal como lo expresamos en este caso.

89 BANFi DEL Río, Cristian (2012) "Breve revisión de la responsabilidad por interferencia de contratos del competidor en Chile". Revista Chilena de Derecho Privado, No 19, diciembre, pp. 174.

90 Boetsch (2011) 52 y 53, expresa que a su entender el Código Civil siguió la teoría ética de la buena fe al definir en el artículo 706 a la posesión. 
la buena fe desde el punto de vista subjetivo ${ }^{91}$, consiste en la convicción de actuar lícitamente en la celebración de un acto o negocio jurídico ${ }^{92}$. De acuerdo a ello, entendemos que la mala fe se configura con el conocimiento ${ }^{93}$ o la posibilidad de conocimiento ${ }^{94}$ que tiene el contratante de la ilicitud ${ }^{95}$ del acto o negocio jurídico que celebra.

91 Pérez Benítez, Jacinto (2013) "Perjuicio patrimonial, interés de grupo y rescisión de garantías otorgadas en la financiación de grupos de sociedades". Revista de Derecho Concursal y Paraconcursal, No 19, p. 156, expresa que el concepto de mala fe y la necesidad de operar con criterio valorativo en su determinación, "merecedora de repulsa ética en el tratamiento jurídico", puede verse en la STS de 7 de diciembre de 2012. Por su parte, la Sentencia del Tribunal Supremo de España, 7 de diciembre de 2012, 8314/2012, fundamento jurídico sexto, establece que "la mala fe va referida a la realización del negocio. Es un concepto jurídico que supone ausencia de buena fe y se apoya en una conducta que debe ser deducida de hechos concluyentes para su apreciación.

"El art. 73.3 LC cuando se refiere a la mala fe en la contraparte del concursado ha querido exigir algo más que el mero conocimiento de la situación de insolvencia o de proximidad a la insolvencia del deudor, así como de los efectos perjudiciales que la transmisión podía ocasionar a los acreedores".

"Así lo ha entendido esta Sala cuando afirma que la mala fe está compuesta por dos aspectos, uno subjetivo y otro objetivo. El subjetivo "no requiere la intención de dańar", sino "la conciencia de que se afecta negativamente -perjuicio- a los demás acreedores, de modo que al agravar o endurecer la situación económica del deudor, se debilita notoriamente la efectividad frente al mismo de los derechos ajenos", y "se complementa con el aspecto objetivo, valorativo de la conducta del acreedor, consistente en que esta sea merecedora de la repulsa ética en el tráfico jurídico" ( Sentencias 548/2010, de 16 de septiembre, y 662/2010, de 27 de octubre )".

92 Boetsch (2011) 53, expresa que “ [...] para el Código la buena fe no es una mera ignorancia, sino que es una "conciencia", esto es, un conocimiento e incluso una convicción de licitud $[\ldots] ”$.

93 Alessandri, Arturo; Somarriva, Manuel; y Vodanovic, Arturo (2009) Tratado de los derechos reales. Santiago: Editorial Jurídica de Chile, pp. 381 y 382.

94 BANFi (2012) 178 seńala que "la mala fe también debe tenerse por probada cuando el demandado, sin saber del contrato ajeno, debía conocerlo, pero su descuido excesivo se lo impidió. En efecto, es pertinente aplicar el criterio que la jurisprudencia ha observado para desestimar demandas de nulidad absoluta interpuestas por quienes celebran un contrato debiendo saber el vicio que lo invalidaba. En estas situaciones, la ley sanciona al contratante que quiere aprovecharse de su propio dolo o torpeza, negándole legitimación activa, como un castigo a la mala fe. "A sabiendas" alude al conocimiento real y efectivo del vicio de nulidad absoluta y no al conocimiento presunto de la ley; a su vez, la expresión "debiendo saber" significa que el sujeto se puso en una posición de ignorancia por su propia negligencia, sobre todo grave, que la ley castiga igualmente que si hubiese actuado de propósito". Por su parte, Alessandri/Somarriva/ Vodanovic (2009) 382 establece que "si se considera buena fe únicamente la que emana de una creencia excusable o diligente, mala fe será no solo el conocimiento de la falta de derecho, de la ilegitimidad de una situación, sino también la creencia errónea, pero no excusable o diligente, de tener un derecho, de actuar legítimamente".

95 No solamente aludiendo a la ilicitud del acto, Alferillo, Pascual (2011) "La mala fe", en: Universitas, No 122, pp. 459 y 460, amplía el ámbito de aplicación de la noción al expresar que "la mala fe se configura cuando el sujeto tiene conocimiento o tiene el deber de conocer determinada situación, circunstancias, datos, condiciones, calidades, etc. relevante para el derecho a la luz de las particularidades propias de cada acto jurídico, cuya utilización antifuncional el ordenamiento jurídico reprueba”. 
Considerando lo anterior en el plano de las acciones revocatorias concursales, la norma del art. 71.1 de la Ley Concursal española establece que serán rescindibles los actos perjudiciales a la masa activa aunque no hubiese existido intención fraudulenta, y la norma del artículo 287 de la Ley nacional habla de revocabilidad objetiva, sin tomar en cuenta -como sí lo hace la norma del artículo 288- el "conocimiento del mal estado de los negocios del deudor" por parte del acreedor. Tales normas nos señalan que aun si el deudor no tenía intención de defraudar a la masa o a los acreedores, y aunque el acreedor no hubiese tenido intención defraudatoria, siempre que el contrato sea perjudicial para la masa activa del concurso, será susceptible de recisión, o revocación, respectivamente.

Si la norma del artículo 287 de la Ley nacional no alude a la intención fraudulenta, como sí lo hace el artículo 2468 del Código Civil -al consagrar la acción pauliana-, o el artículo 288 de la Ley -al consagrar la acción revocatoria concursal subjetiva-, pero a pesar de ello revoca el acto o contrato, entonces no es necesario para la procedencia de la revocación concursal que el acreedor hubiese tenido una intención defraudatoria. Pero sucede que al revocarse el acto o contrato, a pesar de no exigir ánimo o intención defraudatoria en el acreedor, de igual forma y como sanción la Ley subordina automáticamente los créditos que en su beneficio se hubieran originado a partir del ejercicio de la acción revocatoria.

Teniendo en cuenta que, según nuestro parecer, si la Ley subordina el crédito es porque estima que existe mala fe en el acreedor, la mala fe que fundamenta la posposición de su crédito no debemos entenderla configurada con la intención defraudatoria, pues la revocación, como vimos, no pasa por el ánimo de defraudar. Por el contrario, si la revocabilidad objetiva que plantea el artículo 287 pasa por el perjuicio que se haya causado a la masa de acreedores, el cual -ya expresamos- siempre y en todo caso estará presente en los actos o contratos que enumera la disposición ${ }^{96}$, la mala fe que implícitamente estatuye la norma del artículo 292 para fundamentar la subordinación del crédito que se origina con la revocación de un acto o contrato se configurará por el conocimiento o posibilidad de conocimiento que el acreedor tenga del perjuicio que irrogue a la masa la celebración de tal acto o contrato ${ }^{97}$. En estricto rigor

96 Ayuda para esta argumentación lo señalado por SANDoval (2014) 263, al señalar respecto de los actos enumerados en el artículo 287 de la Ley 20.720 de 2014, que son taxativos, y que la disposición "No exige el requisito de mala fe de los contratantes, ya que estos [los actos] por su propia naturaleza envuelven una presunción de mala fe...".

97 En este sentido Ferré (2006) 311, establece que "Siguiendo esta mayoritaria doctrina civilista, podríamos configurar la mala fe, en el ámbito de las acciones de rescisión concursal, a través de un concepto que seguirá la primera de las concepciones doctrinales que hemos recogido y según el cual, en una primera aproximación, se considerará que la mala fe del adquiriente se concretará, bien en su intención de causar un perjuicio patrimonial a los 
-y como lo señaláramos más arriba-, será este un conocimiento en torno a la vulneración de la igualdad jurídica que los acreedores han de tener en el procedimiento concursal ${ }^{98}$, o si se quiere, el respeto de los intereses y derechos de los acreedores dispuestos en la regulación del procedimiento concursal y puesto de manifiesto en el pago proporcional de sus créditos que el orden de prelación de créditos de manera coordinada establece ${ }^{99}$; o bien, un conocimiento en torno al detrimento injustificado del patrimonio del deudor producido por el acto o contrato determinado, que a su vez se traduce en el conocimiento o posibilidad de conocer, mediando diligencia promedio ${ }^{100}$ y propia de los negocios a los cuales comúnmente se dedica $^{101}$, que el acto o contrato no era útil o necesario para la estabilidad y/o beneficio del patrimonio del deudor ${ }^{102}$.

En este sentido, la doctrina comparada se ha pronunciado en la misma forma que venimos señalando al expresar que la mala $\mathrm{fe}^{103}$ en el ámbito de las acciones rescisorias concursales, que motiva posteriormente la subordinación ${ }^{104}$, está dada por el conocimiento que el acreedor haya

acreedores, bien en el conocimiento que haya tenido o podido adquirir de que, a través del referido acto, se causará un perjuicio al común de los acreedores [...]”.

Contreras (2010) 202 y 203, respecto de los pagos anticipados y las hipotecas, prendas anticresis constituidas sobre bienes del fallido para asegurar obligaciones anteriormente contraídas, respectivamente; SANDoval (2014) 270.

99 Goldenberg (2010).

100 Claro Solar, Luis (1932) Explicaciones de Derecho Civil chileno y comparado. Editorial Imprenta Cervantes, tomo VII, p. 493, señala que "Según la ley, 'un justo error en materia de hecho no se opone a la buena fe'; no cualquier error, sino aquel que una persona prudente y que presta a sus negocios el cuidado ordinario y mediano de un buen padre de familia, no está libre de incurrir".

101 BAnfi (2012) 177, expresa que “[...] los conocimientos y la experiencia del demandado en una determinada actividad económica son factores trascendentales para deducir la mala fe y el dolo".

102 Nuestra legislación establece, respecto de la revocabilidad subjetiva del artículo 288, que se entiende que existe perjuicio cuando las estipulaciones contenidas en el acto o contrato se alejan de las condiciones precios que normalmente prevalezcan en el mercado para operaciones similares a la época del acto o contrato. En tal sentido, SAndoval (2014) 269, establece que "ello ocurrirá [existencia de perjuicio a la masa] en el evento que el contratante obtenga con dicho acto o contrato una ventaja apreciable frente a los acreedores".

103 Quetglas (2013) 117: "Respecto de qué constituye mala fe hay que entender que esta se da cuando el acreedor sabía (o no podría ignorar) que al contratar estaba realizando un acto perjudicial para la masa activa y que quien lo efectuaba estaba en situación patrimonial comprometida. Esta posición no es seguida de forma unánime ya que parte de la doctrina exige que concurra un requisito más: la voluntad de perjudicar a los acreedores”. Pérez (2012) 157, señala "En lo que se refiere al problema temporal, es opinión prácticamente unánime que el perjuicio se ha de determinar en el momento en que el acto objeto de examen fue realizado, en atención a las circunstancias entonces concurrentes, y no en relación al momento de ejercicio de la acción o de la declaración de concurso".

104 Recordemos que el artículo 92.6 de la Ley Concursal española establece que procederá la subordinación del crédito que se origine en beneficio del acreedor producto de la acción rescisoria concursal solo si tal acreedor ha sido declarado de mala fe. 
tenido o podido tener de que a través del acto o contrato celebrado se causará un perjuicio a la masa ${ }^{105}$.

En resumen, si aunque el deudor concursado no hubiese pretendido defraudar la masa es posible la revocación del contrato, no será necesario que el acreedor conociera esta intención defraudatoria, sino más bien, a nuestro juicio, el conocimiento o posibilidad de conocer se relacionará con el perjuicio a la masa activa, y en específico, si el acreedor conocía o podía conocer el perjuicio que a la masa activa producía el acto o contrato que con el deudor, futuro concursado, celebraba. Ello configurará la mala fe del acreedor que, ergo, fundamenta la subordinación de su crédito.

Lo anterior no deja de ser relevante desde el punto de vista de la subordinación de créditos que plantea el artículo 292 de nuestra Ley. En efecto, entendiéndose que la mala fe en relación a la revocación concursal está dada por el conocimiento o posibilidad de conocer el perjuicio a la masa activa por parte del acreedor ${ }^{106}$, si este perjuicio -como vimos- es presumido por la Ley en todos los actos o contratos a los cuales hace referencia el artículo 287 en la misma forma que lo hace la Ley Concursal española ${ }^{107}$, y si de acuerdo al artículo 292 todos los créditos que en beneficio del acreedor se generen producto de tal revocación son subordinados en función de la mala fe del acreedor, entonces entendemos que la Ley establece una vinculación directa entre el perjuicio a la masa de acreedores y la mala fe del acreedor que contrata con el deudor para efectos de la revocación y de la subordinación.

En efecto, entendemos que la presunción del artículo 287 no solamente abarcaría el perjuicio patrimonial -como ya lo expresábamos-, sino que la presunción consideraría también la mala fe del acreedor. De otra forma y además, no se explicaría la razón de que la sanción de subor-

105 Ferré (2006) 311, haciendo eco de la doctrina mayoritaria al citar a GUASCH (2004) 1433 y Alcover Grau, G. (2003) "Aproximación al régimen jurídico de la reintegración concursal”. En García Villaverde, R., Alonso Ureba, A., Pulgar Ezquerra, J. (directores): Derecho Concursal. Estudio sistemático de la Ley 22/2003 y de la Ley 8/2003, para la reforma concursal. Madrid; Editorial Dilex, p. 348.

106 Distinto es el parecer de Espigares (2011) 234, para quien "La mala fe debe comportar el conocimiento de la contra parte de que el deudor actuaba para perjudicar a los acreedores; bien lo sabía o no podía ignorarlo". No nos parece acertado esto ya que la misma Ley Concursal establece que no es necesario el ánimo defraudatorio en el concursado, por lo que si este no lo tiene, malamente podría pretenderse del acreedor un conocimiento de un supuesto perjuicio a los demás acreedores.

107 EsCribano (2005) 4025, expresa que "En unos casos - que vamos a conocer como aventajados o favorecidos- la propia norma realiza el juicio de valor, bien por tratare de supuestos en los que la lescividad, preclara, se presume iuret et de iure (art. 71.2 LC) [...]"; reiterándolo en p. 4030. 
dinación se aplique siempre y en todos los casos en que sea revocado un acto o contrato en virtud del artículo 287 de la Ley ${ }^{108}$.

En este sentido y considerando el derecho español, al presumirse iuris et de iure el perjuicio patrimonial en el artículo 71.2 de la LCE, no podrá excusarse quien contrate con el deudor de no haber conocido este perjuicio $^{109}$, con lo que al conocer este perjuicio y de todas forma contratar $^{110}$, se encontrará de mala fe. De acuerdo a esto, y según lo que entendemos por perjuicio para la masa activa y mala fe, el art. 71.2, más que una presunción de derecho de perjuicio patrimonial, contendría una presunción de derecho de mala fe respecto del acreedor que celebra tales actos con el deudor ${ }^{111}$. De esta forma, siempre que algún acto de los seńalados en la norma sea celebrado dentro de los dos años anteriores a la declaración de concurso, existirá mala fe en quien contrata con el deudor, y por tanto, todo crédito en su favor, derivado de la rescisión, deberá ser considerado subordinado en virtud del art. 92.7.

Ahora bien, tal como lo señalábamos para nuestra Ley, desde que siempre los actos y contratos mencionados en el artículo 287 generarán un perjuicio para la masa, se hace imposible la prueba en contrario, tornándose inoficiosa la excepción que la misma norma plantea y por tanto imposible e improcedente la consideración de que el acreedor pudiere encontrarse de alguna manera de buena $\mathrm{fe}^{112}$. Se entiende que como

108 En este sentido, Veiga (2006) 17, se pregunta por qué no es suficiente la rescisión concursal que plantea el artículo 71 de la Ley Concursal española, sino que además tal legislación subordina el crédito del acreedor. No obstante, explica acertadamente, como lo podemos ver de manifiesto en nuestra argumentación, y de acuerdo a lo que seńala la Ley Concursal española, que debería analizarse la actitud defraudatoria o lasciva del acreedor, como lo exige precisamente la norma del artículo $92.6^{\circ}$ de la Ley Concursal española al subordinar el crédito del acreedor cuando ha existido mala fe.

109 En palabras del TS de España, Rol 7265/2012.

110 Ilustrador para este punto puede ser Hidalgo, Pedro (2006) "La inexcusabilidad de la ignorancia de la ley: un principio, una presunción o una ficción”. Revista de Derecho de la Universidad de Concepción, No 119-120, enero-diciembre, pp. 173 - 186.

111 En forma contraria se Espigares (2011) 234, para quien la norma en comento no contiene una presunción de mala fe. Expresa que la ley no señala lo que deberá entenderse por mala fe para el caso de subordinación de crédito del acreedor que fuere declarado de mala fe en el acto impugnado, tampoco pudiendo el autor valerse de presunciones: "No existen tales presunciones legales; ni siquiera en los casos de actos que se presumen perjudiciales por ser realizados a favor de personas especialmente relacionadas con el concursado". En mismo sentido contrario Fernández Seijo, José María (2013) Los efectos de la declaración de concurso sobre los contratos. Barcelona: Editorial Bosch, p. 378. Por otro lado, se infiere que en sentido afirmativo pareciera pronunciarse Aznar (2013) 366, al señalar que "Por ello, si adquirente es una persona especialmente vinculada al deudor concursado, parece bastante complicado que no conozca la situación de insolvencia de este último y la perjudicialidad del acto impugnado".

112 Desde este punto de vista, resulta importante destacar lo señalado por EsCRibano (2005) 4042, al hablar de los efectos de la acción rescisoria concursal. Expresa la autora que "La 
siempre existirá perjuicio para la masa al celebrarse tales actos o contratos, pues la Ley, aunque no expresamente, lo presume de derecho, malamente el acreedor que contrata con el futuro concursado podría alegar que no conocía la consecuencia perjudicial para el patrimonio del deudor, encontrándose por tanto siempre de mala fe $\mathrm{e}^{113}$.

Como vemos, la vinculación entre el perjuicio para la masa y la mala fe en el acreedor a la que hacemos referencia estará caracterizada por la presunción de derecho que establece la Ley respecto del perjuicio a la masa de acreedores, que a su vez trae aparejada la presunción de mala fe del acreedor que celebra con el deudor alguno de los actos o contratos especificados en la norma, y que es la que otorga fundamento a la subordinación del crédito que se origina para el acreedor como efecto de la acción revocatoria. En palabras concretas, cada vez que un acreedor celebre un acto o contrato de los señalados en el artículo 287 del la Ley, como que se presume el perjuicio, y como que la mala fe estará dada por el conocimiento o posibilidad de conocer tal perjuicio por parte del acreedor, existirá por tanto una consideración inmediata de que su actuar es coincidente con un actuar de mala fe $\mathrm{e}^{114}$, por lo que estará sometido a la subordinación del eventual crédito que se origine en su beneficio por efecto de la revocación del acto o contrato.

A nuestro parecer, implícitamente esta presunción no la habría querido el legislador, motivo por el cual habría introducido en el artículo 287, como vimos de manera inútil, la excepción a la revocación de los actos y contratos en caso de acreditarse la falta de perjuicio para la masa.

lesión patrimonial presunta iuris et de iure, iuris tantum, o en otro caso, probada, opera como fundamento bastante para exigir al adquiriente la restitución de los bienes o derechos percibidos, siendo por tanto, indiferente la existencia o no de fraude [...]".

113 Cobra aplicación lo seńalado por Hidalgo (2006) 179 a 181, en torno a la doctrina mayoritaria. Del mismo modo, Baeza Ovalle, Gonzalo (2013) Derecho concursal chileno. Legislación vigente y reforma proyectada, $1^{\text {a }}$ edición. Editorial Thomson Reuters, p. 754.

114 En este punto, aclaratorio de lo argumentado es lo explicado por AlesSANDri/SomarRiva/ Vodanovic (2009) 385, al hablar de la influencia del error de derecho en la buena fe. Expresa que "[...] el error en materia de derecho constituye una presunción de mala fe, que no admite prueba en contrario (art. 706, inc. final). Es una consecuencia del principio de que nadie puede alegar ignorancia de la ley después que esta haya entrado en vigencia (art. 80)". Si bien es cierto el autor establece una aplicación restrictiva de la presunción de mala fe por error de derecho a la posesión, importante es lo considerado por BAEZA (2013) 754, para quien sería factible que el legislador, tomando en cuenta el bien jurídico protegido, presuma la mala fe para las acciones revocatorias concursales, tal como lo hace en el artículo 706 del Código Civil. 


\section{2) MALA FE DEL ACREEDOR EN LA SUBORDINACIÓN DEL CRÉDITO EN LA REVOCABILIDAD SUBJETIVA}

Como ya lo señaláramos, el conocimiento que se exigirá al acreedor para estimar su mala fe, y consecuente subordinación del crédito que detente respecto del deudor en caso de revocación concursal, se refiere al perjuicio en el patrimonio del deudor.

Lo anterior, respecto del artículo 287 de la Ley, se entenderá en todo caso al existir una presunción de mala fe en el actuar del acreedor. Y esto no es un tema menor, pues el hecho de que la mala fe del acreedor se defina con su conocimiento o posibilidad de conocer el perjuicio al patrimonio del deudor, futuro concursado, importa que respecto del artículo 288 de la Ley nos preguntemos si sucede lo mismo, y de no ser así, ¿qué conocimiento, y qué grado de conocimiento o posibilidad de conocimiento deberemos exigir al acreedor para considerarlo parte de mala fe en el acto impugnado, esto es, para justificar la subordinación de su crédito?

Si analizamos el tenor del artículo 288 de la Ley podemos ver que para la revocabilidad subjetiva, además del perjuicio a la masa de acreedores, la norma requiere la existencia de un conocimiento por parte del contratante del mal estado de los negocios del deudor ${ }^{115}$.

Considerando lo explicado hasta ahora, podríamos decir a priori que no solo sería suficiente para configurar la mala fe del acreedor, y así fundar la subordinación de su crédito, el conocimiento del perjuicio que con el acto o contrato se causa a la masa de acreedores -en los términos que ya latamente hemos señalado-, sino también el conocimiento del mal estado de los negocios del deudor. Pero por otro lado, también podríamos decir que, en este especial caso que a primera vista parece una reminiscencia del artículo 2468 del Código Civil, a diferencia de lo que ocurre con el artículo 287 y siguiendo su tenor literal, el fundamento de la subordinación, si bien presente en la mala fe, pasaría por el conocimiento que el acreedor tenga del mal estado de los negocios del deudor, más que por el conocimiento o posibilidad de conocimiento del perjuicio para la masa de acreedores. Veámoslo a través de una comparación con el caso español.

En el artículo 72.3 de la LCE, se mencionan ciertos actos respecto de los cuales se presume, iuris tantum ${ }^{116}$, esto es, de forma simplemente legal, el perjuicio patrimonial del deudor. En tal situación, no se puede

\footnotetext{
115 Contreras (2010) 204, señala para el artículo 77 de la antigua Ley de Quiebras que se requiere que los acreedores pagados y los que hubieran contratado con el fallido hayan tenido conocimiento de la cesación de pagos, más que del mal estado de los negocios del deudor. Quetglas (2013) 68; Massaguer (2014) 202.
} 
establecer que para la subordinación a la que hace referencia el artículo 92.6 $6^{\circ}$ exista una presunción de mala fe respecto del acreedor que puede conocer el perjuicio, toda vez que la norma del artículo 72.3 no establece que tratándose de tales actos siempre y en todo caso lo existirá. Quien contrata con el deudor no necesariamente lo hará en conocimiento del perjuicio a su patrimonio. Ahora bien, podría señalarse que la norma pone al corriente al acreedor de la posibilidad que con la celebración de tales actos se produzca un perjuicio al patrimonio del deudor, y debido a que la mala fe en el acreedor no solo se produce por el conocimiento efectivo de este perjuicio sino también por la posibilidad de conocerlo, al no existir prueba en contrario durante el proceso que descarte el perjuicio, deberemos entender que el acreedor se encuentra en mala fe toda vez que existía conciencia de la posibilidad de causar un daño al patrimonio del deudor, y en tal caso, a sus acreedores. Sin embargo, no se puede decir que esto se equipare a una presunción de mala fe a efectos del art. 92.6 ${ }^{\circ}$ pues aún el acreedor puede probar que no ha habido perjuicio ${ }^{117}$, y por tanto, que no ha habido mala fe.

Con esto en mente y volviendo a nuestra Ley, apreciamos que similar norma se encuentra establecida en el artículo 288. En esta no existe una presunción de derecho de perjuicio patrimonial, puesto que no establece una categoría específica de actos o contratos respecto de los cuales sea posible afirmar que con su celebración se producirá siempre y en todo caso un perjuicio al patrimonio del deudor, y consecuencialmente, un perjuicio a la masa de acreedores. Siendo eventual el perjuicio para la masa, no necesariamente habrá un conocimiento de tal situación por aquel que contrató con el deudor, futuro concursado.

Por ello es que no podemos expresar que, respecto del artículo 288 de la Ley nacional, exista una presunción de perjuicio en todo caso y sin excepción alguna, y que pueda vincularse a la mala fe del acreedor, para efectos de subordinar su crédito -como sí sucede respecto del artículo 287 en relación al artículo 292 de la Ley-. En otras palabras, no existe presunción de mala fe del acreedor para fundamentar la subordinación del crédito que en su beneficio pueda originarse a raíz de los efectos de la revocación de un acto o contrato en virtud del artículo 288 de la Ley.

Teniendo esto claro, y considerando que la mala fe del acreedor -ya lo hemos dicho- es el fundamento de la subordinación de su crédito, nos

117 SANCho (2012) 1147, expresa que "Fuera de estos supuestos, cuando el acto de disposición no es a título gratuito, en la medida que suponga un detrimento patrimonial deberán examinarse las circunstancias que concurren para apreciar su justificación, que va más allá de los motivos subjetivos, y conforman el interés económico patrimonial que explica su realización”. 
preguntamos: ¿qué configura la mala fe que justifica la subordinación del crédito derivado de la revocación subjetiva del artículo 288 de la Ley?, pues la norma establece que para la procedencia de la revocación concursal debe existir, además del perjuicio a la masa de acreedores, un conocimiento del mal estado de los negocios del deudor. Bajo esta perspectiva entonces, y para efectos de la subordinación del crédito, ¿la mala fe del acreedor pasará por el conocimiento o posibilidad de conocimiento del perjuicio a la masa de acreedores; por el conocimiento o posibilidad de conocimiento del mal estado de los negocios del deudor; por el conocimiento o posibilidad de conocimiento de ambos?

Lo anterior es de sobremanera importante, toda vez que tras requerir la Ley mala fe en el acreedor para subordinar el crédito en aplicación del artículo 292, al no presumir el artículo 288 la mala fe como lo hace el artículo 287, y al no contemplar un periodo en el que se presuma que respecto de ciertos actos existirá mala fe como lo hacía la antigua Ley de Quiebras ${ }^{118}$-que especificaba un término de diez días previos a la fecha de cesación de pagos ${ }^{119}$-, el tiempo de uno o dos ańos anteriores al inicio del concurso que establece hoy nuestra Ley ${ }^{120}$ es un tiempo muy largo en el que cualquier acto o contrato podría celebrarse entre el deudor y un acreedor cualquiera. Respecto de este acreedor, su tranquilidad será coincidente con la certeza que tenga respecto de lo que esperar si contrata con el deudor, lo que en términos jurídicos significa saber en qué circunstancias se encontrará de mala fe, y en términos prácticos conocer en qué circunstancias las acciones que lleva a cabo serán suficientes para ser estimado de buena fe, de manera de no ver revocado el acto o contrato, y consecuentemente no ver subordinado el crédito que en su beneficio se origine.

118 La antigua Ley de Quiebras regulaba la inoponibilidad de los actos y contratos que hoy se encuentra establecidos en el artículo 287 de la Ley respecto de las acción revocatoria concursal objetiva. Contreras (2010) 191, señala la importancia que repercutía para la procedencia de las acciones de reintegración de la antigua Ley de Quiebras la determinación por parte del juez de la fecha de cesación de pagos.

119 La antigua Ley de Quiebras establecía en su artículo 74 que son inoponibles a la masa los actos y contratos a título gratuito celebrados con el deudor desde los diez días previos a la fecha de cesación de pagos y hasta el día de la declaración de la quiebra. Por su parte, el 76 de la misma ley establecía que "Son inoponibles a la masa los siguientes actos o contratos ejecutados o celebrados por el deudor desde los diez días anteriores a la fecha de cesación de pagos y hasta el día de la declaración de quiebra...”. En este sentido, Rodríguez Lazo, Carlos (1937) Sintesis de la teoría general de las obligaciones. Editorial Nascimento, p. 37, señala que se requiere como requisito para la procedencia de la acción pauliana que el deudor haya tenido conocimiento del mal estado de sus negocios, y que eso el acreedor debe probarlo, salvo si el acto se realizó dentro de los 10 días anteriores a la cesación de pagos del artículo 72 de la antigua Ley de Quiebras.

120 Artículo 287 y 288 de la Ley No 20.720 de 2014. 


\section{(2.1.) Mal ESTAdo De LOS Negocios Del DeUdor Y SUbordinación DEL CRÉDITO DEL ACREEDOR}

De acuerdo a lo que ha señalado la doctrina, se estima que el mal estado de los negocios del deudor es una expresión coincidente con la de insolvencia, y a su vez, con la expresión "cesación de pagos"121. Otros autores, no obstante, las distinguen ${ }^{122}$. Por otro lado, se ha dicho que la cesación de pagos es un estado patrimonial del deudor caracterizado por la imposibilidad de hacer frente a sus obligaciones ${ }^{123}$. Finalmente, y para dejar visible este estado patrimonial del deudor, nuestra Ley, al igual que la antigua Ley de Quiebras, establece ciertos casos que darán cuenta de aquel: son los llamados hechos reveladores ${ }^{124}$, que dan noticia del mal estado patrimonial del deudor.

Teniendo esto claro, la interrogante en torno a la mala fe y el mal estado de los negocios del deudor se reduce a establecer que, coincidiendo la cesación de pagos con un estado patrimonial, el conocimiento que se requeriría de parte del acreedor para estimarlo de mala fe debiera vincularse necesariamente al del estado patrimonial del deudor, y que en la mayoría de los casos, pero no único, trae aparejada como consecuencia la imposibilidad de pago de sus acreencias, esto es, la insolvencia ${ }^{125}$. En palabras simples, el acreedor de mala fe para efectos del artículo 288 de la Ley sería aquel que hubiese conocido o podido conocer el mal estado patrimonial del deudor, futuro concursado.

Ahora bien, y no obstante lo anterior, poco o nada nos podría servir aludir al conocimiento por parte del acreedor de los mencionados hechos reveladores para justificar la existencia de mala fe, y consecuentemente una sanción como la subordinación de su crédito, toda vez que de acuerdo a la redacción del artículo 288 el acreedor podría haber contratado con mucho tiempo de antelación al inicio del concurso, incluso, y por qué no decirlo en casos más extremos -pero no por ello improcedentes-, hasta dos años antes de su manifestación. En efecto, sucede que ni los

121 En tal sentido se pronuncia Puga (2014) 54, hace sinónimos la expresión a "cesación de pagos". De igual forma Sandoval (2014) 70 y 71. Por su parte, Román Rodríguez, Juan Pablo (2001) Salvamento de empresas en crisis. Santiago: Editorial Jurídica de Chile, p. 169, estima que insolvencia y cesación de pagos son dos conceptos diferentes.

122 En este sentido Román (2001) 167.

123 Puga (2014) 54; Sandoval (2014) 255; Román (2001) 177.

124 Sandoval (2007) 41, expresa que son hechos que sean el efecto del estado patrimonial del deudor y que permitan deducir que tal causa los origina; Gómez/Eyzaguirre (2009) 132.

125 Gómez/Eyzaguirre (2009) 40, señala que el hecho revelador por antonomasia de la insolvencia es la cesación de pagos u otros equiparables. En este mismo sentido, Román (2001) 166. 
hechos reveladores se manifiestan necesariamente con un tiempo considerable de antelación al concurso, ni los antecedentes que motivan tales hechos - no los hechos reveladores mismos- se encuentran a la vista del público, permaneciendo por mucho tiempo en el ámbito privado del deudor, siendo muy difícil su conocimiento por parte del acreedor contratan$\mathrm{te}^{126}$.

Al tiempo de manifestarse claramente el estado patrimonial al que hacemos referencia mediante los hechos reveladores se faculta a los acreedores a solicitar el concurso ${ }^{127}$, pero a esta altura puede suceder que existan casos en que ya se haya contratado con el deudor con mucho tiempo de antelación, pero siempre dentro de los dos ańos anteriores al inicio del concurso ${ }^{128} \mathrm{o}$, incluso, anteriores a la manifestación de los hechos reveladores. ¿Qué debemos exigir entonces a tal acreedor?, pues al tiempo de la celebración del acto o contrato no se imaginaba que en un futuro no muy lejano se abriría un procedimiento concursal respecto de su deudor, que su contrato podría ser revocado y su crédito, peor aún, subordinado a un lugar posterior al de los acreedores valistas, donde con seguridad poco o nada recibiría en pago por su acreencia.

Es claro que si el acreedor conocía la situación patrimonial del deudor no existirá problema, toda vez que se manifiesta por este hecho la mala fe que fundamenta la sanción de revocación concursal y posterior subordinación de su crédito. El problema se produce al saber que la mala fe también pasa por el poder haber conocido el estado patrimonial del deudor, esto es, la posibilidad de que el acreedor pueda haber conocido el estado patrimonial del deudor a través de una serie de acciones, gestiones,

126 En este sentido, Palao (2013) 43, refiriéndose a la importancia de la anticipación de la insolvencia en el concurso, expresa que "[...] cuando la insolvencia se exterioriza y muestra su sintomatología a terceros en forma de impagos, es posible que sea demasiado tarde.[...]”. En igual sentido, en la Historia de la Ley No 20.720, Informe de la Comisión de Constitución, p. 16, el profesor Juan Esteban Puga Vial expuso que "[...] El efecto acelerador de la pobreza implica regularmente que un deudor insolvente pierde todo interés en su empresa, pues esta rápidamente llega a patrimonio cero o negativo. De allí para adelante está administrando recursos de los acreedores. Sin embargo, estos padecen tres ignorancias: no saben de verdad la composición del patrimonio del deudor; no saben tampoco del negocio del deudor y, por último, no se conocen entre ellos y dados sus intereses contrapuestos, existen fundadas suspicacias. Todo ello afecta a una eficaz y oportuna intervención. Tales ignorancias no las sufre el deudor, pero él tiene motivos también para retrasar la manifestación de su estado.[...] una buena ley concursal debe hacerse cargo de este problema si se desea contar con un deudor cooperador y no un deudor suspicaz al sistema. Puesto que es el primero en conocer de su estado, un sistema concursal debe ser cuidadoso con él, no en su beneficio, sino que en el de los acreedores".

127 Sandoval (2007) 44.

128 Recordemos que el artículo 288 de la Ley establece que la revocación procederá respecto de aquellos actos o contratos que hayan sido celebrados hasta con dos años de antelación a la fecha de declaración de concurso. 
indagaciones, y que en caso de no llevarlas a cabo, también significaría estimarlo acreedor de mala fe ${ }^{129}$. Ya hemos dicho, se trata de conocer o poder haber conocido el estado patrimonial del deudor. Ante esto, ¿qué debemos esperar o exigir entonces a este acreedor para estimarlo de buena fe?

Se aprecia que la complejidad de la determinación del mal estado de los negocios previo al concurso, esto es, previo a que se revele tal situación, tiene como premisa la complejidad de la determinación del estado de cesación de pagos o bien, el estado patrimonial del deudor previo al concurso. Solo la empresa podrá conocer tal situación ${ }^{130}$, y con ello en mente, no es posible exigir al acreedor, para apreciar la situación patrimonial o financiera de una empresa deudora, que realice gestiones o indagaciones más allá de lo que, por ejemplo, pudiere apreciarse a través del estudio de las solemnidades que por vía de publicidad establece la ley en determinados casos; solemnidades por vía de publicidad que, por lo demás, no necesariamente darán cuenta efectiva del real estado patrimonial y financiero del cocontratante deudor, y que aún pudiere dejarlo en la incertidumbre de no conocer su real estado patrimonial.

La contrapartida de tal situación se aprecia en el hecho de que salvo los muy pocos casos - consideramos casi inexistentes atendida la difícil prueba- en que el interesado en revocar el acto o contrato tenga pruebas que den cuenta del conocimiento efectivo del acreedor del mal estado patrimonial del deudor al tiempo de contratar; en los restantes casos -que estimamos mayoría- no sería posible determinar la mala fe del acreedor que contrata con el deudor. Ello acarrearía el problema de la imposibilidad de revocar el acto o contrato, y consecuencialmente subordinar el crédito que de tal revocación se origine en beneficio del acreedor, incluso y a pesar de que aquel acto o contrato hubiere producido un perjuicio a la masa de acreedores ${ }^{131}$. Se aprecia en este punto una contradicción clara entre esta paradójica situación que se genera con la norma en comento y

129 BANFi (2012) 138.

130 Pérez Ragone, Álvaro y Martínez Benavides, Patricio (2015) "Del sobreendeudamiento a la insolvencia: fases de crisis del deudor desde el derecho comparado". Revista Chilena de Derecho, Vol. 42, No 1, p. 95.

131 En este sentido, ya SANDoval López, Ricardo (2007) La Insolvencia de la empresa. Derecho Concursal: quiebra, convenio y cesión de bienes. 6a edición. Santiago: Editorial Jurídica de Chile, tomo VI, p. 38, señalaba que en la práctica la adopción de la teoría intermedia -refiriéndose a la teoría intermedia que da cuenta del estado de cesación de pagos- origina inconveniente en lo que se refiere a los efectos retroactivos de la quiebra, al resultar muy breve el periodo sospechoso previo al inicio del concurso, toda vez que para determinar la fecha de cesación de pagos el juez debiera establecer primero la del incumplimiento, con lo cual muchos casos de actos y contratos anteriores quedarían fuera de este efecto retroactivo. De acuerdo a esto, y lo señalado por nosotros, vemos que tal situación se genera incluso con la teoría amplia o moderna de la cesación de pagos. 
el espíritu protector de los intereses de los acreedores que esgrime la misma Ley.

Entonces, entendido lo anterior y para evitar tal contradicción, ¿es que tenemos que exigir al acreedor, previo a la celebración del acto o contrato, que se cerciore, sin lugar a dudas, que la empresa no tiene problemas patrimoniales y financieros?, ¿es necesario que el acreedor vaya tan lejos en sus indagaciones que deba inmiscuirse en la situación financiera, económica interna, y a la vez poco visible públicamente, de una empresa? Al parecer la ley lo estaría exigiendo de forma implícita, o a lo menos respecto de aquellas empresas en que tal análisis podría ser de algún modo más fácil, como en el caso que deban llevar contabilidad a través de libros, balances, estados financieros, que participen en la bolsa de valores, que se encuentren sometidas a fiscalización por la Superintendencia de Valores y Seguros (SVS), etc. Pero sucede que formas de analizar la situación patrimonial y financiera de una empresa hay muchas, pero no todas son de libre o fácil acceso al público ${ }^{132}$, esto es, eventuales contratantes de la empresa (futura deudora). Entonces ¿qué exigir al acreedor?, ¿qué exigir al acreedor en aquellos casos en que, por ejemplo, su futuro deudor sea pequeña y mediana empresa (PYME), no lleve contabilidad, no se encuentre sometida a fiscalización por la SVS, o que esté amparada por el secreto o confidencialidad de la contabilidad ${ }^{133}$ ?

Creo que estamos de acuerdo en que es del todo excesiva la exigencia que establece el artículo 288 de la Ley desde el punto de vista de su espíritu; más si sabemos que en el mundo de la actividad privada comercial la presunción de buena fe es la que debe primar.

Tal como se encuentra redactada la Ley, nos parece que cualquier acreedor que pretenda contratar con una empresa debería partir de la base de estimar que la empresa se encuentra mal económicamente, para evitar una sanción futura. Pareciera ser que la presunción es la contraria, esto es, la mala fe, si nos ponemos en lugar del acreedor que pretende contratar con una empresa y desde esta perspectiva pensamos en un eventual procedimiento concursal. Y no es que sea malo estimar la mala fe del acreedor una vez se haya abierto el procedimiento concursal, con lo que se protege efectivamente la par conditio creditorum de acuerdo al espíritu de la Ley. Pero esto mismo, antes de que se inicie el procedimiento concursal, seis

132 En este sentido Pérez/Martínez (2015) 95, nos ponen de manifiesto el problema de la indagación sobre el real estado patrimonial de una empresa, indicando que la insolvencia no se exterioriza en un hecho simple, necesitándose tener en cuenta para su determinación diversos elementos, como son, citando a Frade (2012), la calidad personal del deudor, acceso al crédito, activo, pasivo a corto, mediano y largo plazo, condiciones del mercado, capacidad productiva, entre otros.

133 Pérez/Martínez (2015) 95 lo señalan como ejemplo que dificulta la indagación sobre el real situación de solvencia o no del patrimonio de una empresa. 
meses, un año, dos años anteriores al inicio del concurso, parece una exageración... ¿bajo qué fundamento se justifica que el acreedor debiera considerar o representarse, al momento de contratar, que su cocontratante "posiblemente" o "probablemente" vaya a incurrir en situación de concurso que le pudiere repercutir consecuencias desfavorables a sus intereses?

Como vemos, lo paradójico de la norma se manifiesta en el hecho de que para considerar al acreedor de buena fe, se debe estimar que este mismo acreedor al momento de plantearse contratar debería partir de la base de presumir la mala fe de su cocontratante -el deudor-, y así realizar innumerables gestiones e indagaciones para cerciorarse, sin lugar a dudas, sobre de la situación patrimonial y financiera del deudor, con tal de eliminar de forma irrefutable la posibilidad de que su deudor se encuentre en una situación patrimonial desmejorada, y por tanto eliminar la posibilidad de que en el futuro sea considerado como acreedor de mala fe en un "eventual procedimiento concursal". Todo acreedor que pretenda contratar con un deudor, para evitar ser considerado acreedor de mala fe en un "probable procedimiento concursal futuro", debería partir de la base de que el deudor se encuentra posiblemente en problemas financieros y por tanto realizar innumerables indagaciones y gestiones para eliminar de manera completa tal posibilidad. Solo de esa forma podría estar tranquilo, celebrar el acto o contrato, sin la incertidumbre de la posibilidad de que en el futuro sea revocado su contrato al considerársele acreedor de mala fe, y lo que es peor, ver subordinado su crédito a un lugar posterior al de los acreedores valistas, donde poco o incluso nada recibirá en pago por su acreencia.

Lo anteriormente descrito es del todo ilógico y contradictorio, apreciándose con mayor fuerza si pensamos que, al tiempo de contratar, el acreedor ni siquiera tendría por qué habérselo representado ${ }^{134}$. ¿La consecuencia?: un evidente desincentivo a la contratación.

\section{3) NECESIDAD DE UNA REFORMA A MODO DE CONCLUSIÓN}

Del estudio de la Historia de la Ley No 20.720, podemos apreciar que el texto original del proyecto ${ }^{135}$ no contenía el efecto subordinativo

\footnotetext{
134 En este sentido, SANDoval (2014) 257, pone en evidencia el problema, que también puede tener injerencia importante en lo que venimos diciendo, en torno a dilucidar cuándo está iniciado un procedimiento concursal, para efectos del cómputo del plazo de dos ańos a los que hace referencia la norma en comento.

135 Boletín No 8324-03 del Senado, Proyecto de Ley que sustituye el régimen concursal vigente por una ley de reorganización y liquidación de empresas y personas, y perfecciona el rol de la Superintendencia del ramo, de 23 de mayo de 2012.
} 
en las acciones revocatorias concursales ${ }^{136}$. Fue durante el análisis del proyecto que efectuara la Comisión de Constitución de la Cámara de Diputados, en segundo trámite constitucional, donde se instó por modificar el antiguo artículo 294, actual 292, agregando el efecto en comento. Tal decisión, podemos apreciar se debió a los comentarios que invitados afines al área realizaran durante el debate en la Comisión. En tal sentido, se esgrimió que si bien la norma era innovadora, de igual forma albergaba y posibilitaba que acreedores celebraran actos perjudiciales para con el deudor, puesto que se contenía -y aún se contiene- la posibilidad de enervar la acción pagando el precio justo ${ }^{137}$, así como la posibilidad de que el acreedor pudiere beneficiarse en el concurso, a pesar de haber defraudado a la masa, al poder verificar el crédito que se origina en su favor al operar la revocación del acto o contrato respectivo ${ }^{138}$. Atendidas tales consideraciones, se decidió por la Comisión incorporar como sanción ${ }^{139}$ el efecto subordinativo a las acciones revocatorias concursales.

Consideramos que se encuentra plenamente justificada la incorporación de este especial efecto a las acciones revocatorias concursales, puesto que de lo contrario $-y$ como indicábamos en el acápite relativo a la naturaleza jurídica de esta institución y en el relacionado a la mala fe como fundamento de la subordinación del artículo 292- actos constitutivos de abuso de derecho ${ }^{140}$ y por tanto atentatorios contra la buena $\mathrm{fe}^{141}$, de igual forma reportarían un tratamiento beneficioso y un prove-

136 El texto original del artículo 294 -actual 292- del Proyecto de Ley indicaba en lo pertinente que "La parte condenada deberá restituir efectivamente la cosa a la parte que obtuvo en juicio y tendrá derecho a la devolución de lo que hubiera pagado con ocasión del acto o contrato revocado, debiendo verificar ese monto en el Procedimiento Concursal respectivo a cuyo nombre se dedujo la acción. [...]”.

137 De la Historia de la Ley No 20.720, Informe de Comisión de Constitución, p. 201, se aprecia que Juan Esteban Puga Vial, interviniendo en la Comisión de Constitución de la Cámara de Diputados, en segundo trámite constitucional, indicó "que si bien esta norma plantea una innovación interesante, de algún modo estimula a terceros para asumir los riesgos de celebrar actos perjudiciales a los acreedores, pues siempre tienen la posibilidad de impedir la acción pagano el precio justo".

138 En la Historia de la Ley No 20.720, Informe de Comisión de Constitución, p. 201, la Superintendenta de Quiebras, abierto el debate en la Comisión de Constitución de la Cámara de Diputados, en segundo trámite constitucional, y en respuesta a los comentarios efectuados por el profesor Juan Esteban Puga Vial, indicó la necesidad de subordinar el pago del monto verificado en el procedimiento concursal por el contratante vencido, "ya que de lo contrario, se produciría un beneficio para dicho contratante, quien podría recuperar lo pagado, a pesar de haber participado en la celebración de un acto revocable".

139 El profesor Juan Esteban Puga Vial hizo presente en su opinión ante la Comisión que era necesario establecer una sanción adicional para disuadir tales conductas. En mismo sentido Goldenberg (2015) 103.

140 Larraín (2003) 290; Ferré (2006) 315; Díez Soto (2006) 82.

141 Barros (2010) 349; Alessandri/Somarriva/Vodanovic (1990) 64, citando además a Díez-Picazo (1963) 141; Garrido (2004) 1668; Ferré (2006) 315; Alemany (2004) 1886; Alonso (2004) 930; Veiga (2006) 17; Linacero (2005) 264 - 267. 
cho injustificado al acreedor. En efecto, de no mediar la subordinación de su crédito, y a pesar de la revocación del acto o contrato respectivo, el acreedor sujeto pasivo de la acción se vería beneficiado con el crédito que se origina en su favor, pues conservando la calidad de tal, aun podría verificar su crédito y participar en el reparto del patrimonio del deudor junto al resto de acreedores en el orden de prelación respectivo, a pesar de haber causado un perjuicio a la masa, en clara contradicción con el principio de buena fe.

Sin perjuicio de lo anterior, teniendo en cuenta las implicancias y alcances que la regulación actual de las acciones revocatorias concursales y su efecto subordinativo presentan, principalmente en cuanto a la certeza jurídica de los acreedores que pretenden contratar con el deudor, futuro concursado -latamente descritas en los apartados anteriores-, consideramos preciso efectuar algunos comentarios que posibiliten una conjugación armónica entre los fines pretendidos por la Ley en torno a la preocupación por los intereses de todos los acreedores concursales, la buena fe y el fomento de la contratación con el deudor.

En este sentido, podríamos estimar que es el juez el llamado a resolver el problema de la falta de certeza jurídica de los acreedores que contratan con un deudor cualquiera, originada por las dificultades probatorias que se desprenden de la interpretación sistemática de las normas que gobiernan las acciones revocatorias concursales y sus efectos; tal como lo señalaba alguna doctrina en relación a los problemas suscitados en torno a la necesidad de prueba por parte del acreedor del estado de cesación de pagos, para la procedencia de la revocación en virtud del artículo 77 de la antigua Ley de Quiebras ${ }^{142}$.

Sin embargo, estimamos que la mejor solución pasaría por entregar mayor certeza jurídica a los acreedores que contratan con el deudor, futuro concursado, al momento mismo de contratar.

Para ello debiéramos considerar que o delimitamos de una vez por todas el concepto de insolvencia en nuestra Ley, de forma de incorporar situaciones concretas antes de la manifestación del mal estado de los negocios del deudor ${ }^{143}$, o bien, consideramos que en el ámbito de la acción revocatoria concursal -base de la subordinación del crédito del acreedor que contrata con mucho tiempo de antelación al inicio del concurso o a la manifestación de los hechos reveladores-, debe operar un criterio o teo-

\footnotetext{
142 Contreras (2010) 204.

143 En este sentido, Pérez/Martínez (2015) 97, establecen la importancia de la necesidad de fijar el momento a partir del cual debemos entender que existe un riesgo a la viabilidad económica de la empresa.
} 
ría de la cesación de pagos distinta ${ }^{144}$. En este último sentido, debiera ser una teoría que incorpore el estado del concurso mismo, el momento que posibilita su inicio, así como el momento previo ${ }^{145}$.

A modo de ejemplo, en la doctrina de la "crisis" del derecho francés, existe un estado de preinsolvencia, no igual a la insolvencia potencial, en el que se requiere cierto grado de certidumbre respecto de la llegada de la cesación de pagos a través de la existencia de situaciones de determinada gravedad ${ }^{146}$. Se establece un sistema de alerta que busca generar un diagnóstico de la situación de la empresa mediante un concepto amplio del presupuesto de la quiebra que permita considerar la existencia de antecedentes que puedan hacer razonablemente prever la existencia de un desequilibrio o problema financiero que ponga en riesgo a la empresa ${ }^{147}$.

Distinta es la situación en el derecho alemán, en el cual al presupuesto principal del concurso -o cesación de pagos-, como causa adicional para su apertura se contempla el sobreendeudamiento o überschuldung, el cual se reserva para las personas jurídicas que padezcan un desbalance económico, esto es, que no dispongan de un patrimonio activo suficiente como para cubrir sus deudas, aunque ello no se haya traducido en una incapacidad de pago ${ }^{148}$. Para esta doctrina, importante es el hecho de que la valoración del desbalance patrimonial no se realiza solo confrontando el activo y el pasivo del deudor, sino que se utiliza un criterio dinámico en que se contrasta el crédito que posee el acreedor y su capacidad de recuperación ${ }^{149}$.

Finalmente, estatuyéndose la insolvencia inminente en el derecho español como el estado patrimonial del deudor que prevé que no po-

144 Para un complemento en torno a las repercusiones que en esta materia presenta el problema del tiempo de inicio de un procedimiento concursal, Goldenberg Serrano, Juan Luis (2012) "El problema temporal del inicio de los procedimientos concursales". Revista Ius et Praxis, año 18, No 1, p. 317.

145 Pérez/Martínez (2015) 107, dan cuenta de algunas ventajas que presenta la consideración de la iliquidez como una estado que trasciende en el tiempo. Señalan que "En realidad no se requiere "una iliquidez por en un solo momento en el tiempo", sino además que tenga una duración prolongada.

"Este examen permite ver la iliquidez en el tiempo, que se considera no solo al momento de la apertura del procedimiento concursal, sino que podría servir posteriormente o incluso [en lo que nos interesa] para antes".

146 Pérez/Martínez (2015) 115, refiriéndose al caso del derecho francés en torno a la causal de insolvencia fundada en la amenaza de iliquidez o inminente insolvencia. Esta descripción de la teoría de la crisis del derecho francés es descrita en términos señalados por PugA (2014) 72.

147 Goldenberg (2012) 338.

148 Trujillo (2003) 11.

149 Pulgar Ezquerra, Juana (2005) La declaración del concurso de acreedores. Madrid: Editorial La Ley, p. 319. 
drá cumplir regular y puntualmente sus obligaciones ${ }^{150}$, resulta interesante poner atención en las soluciones que el ordenamiento societario comprende como alertas o formas de anticipar el concurso, y que dan cuenta de la influencia o relación entre el equilibrio contable o balance económico de la empresa y su solvencia ${ }^{151}$. En tal ámbito de cuestiones, destaca que la trasposición que la Ley de Sociedades de Capital ${ }^{152}$ espańola efectuó de la Directiva Europea 77/91/CEE, de 13 de diciembre de 1976, obligue la disolución y liquidación de las empresas si sus fondos propios disminuyen por debajo de la cifra de capital declarado. Para esta legislación, el fundamento de esta regulación se encuentra en que la falta de capital o fondos propios de la empresa obligaría a los terceros a asumir los riesgos empresariales del deudor, ya que el patrimonio del deudor es la única garantía de pago de sus acreencias ${ }^{153}$.

Considerando formas como las mencionadas a modo de ejemplo154, nuestra legislación incorporaría un grado importante de certeza en relación a lo que debiera entenderse como mal estado de los negocios del deudor, tanto para efectos de determinar la mala fe en la acción revocatoria del artículo 288, como para justificar la posterior subordinación del crédito del acreedor que se origina tras la revocación ${ }^{155}$ del acto o contrato.

Ahora bien, sin perjuicio de lo anterior y para una mayor coordinación entre los fines pretendidos por la Ley en torno a la preocupación por los intereses de todos los acreedores concursales, la protección de la buena fe y el fomento a la contratación con el deudor, como planteamiento de lege ferenda proponemos eliminar derechamente la alusión que el artículo 288 hace al "conocimiento del mal estado de los negocios del deudor" como requisitos de procedencia de la revocación concursal de los actos y contratos celebrados con el deudor, y consecuencialmente de procedencia de la subordinación del crédito que de la revocación de tales actos o

150 Artículo 2.3 de la Ley Concursal española. Goldenberg (2012) 336.

151 Palao (2013) 121. Para Pérez/Martínez (2015) 96, en el sobreendeudamiento y la insolvencia inminente "[...] se examinan elementos cuantitativos y cualitativos actuales y futuros en base a los cuales se amplían las maniobras de salvataje o reorganización oportuna de la empresa".

152 Real Decreto Legislativo 1/2010, de 2 de julio, por el que se aprueba el texto refundido de la Ley de Sociedades de Capital. Boletín Oficial del Estado, No 161, de 3 de julio de 2010.

153 Palao (2013) 150 y 151.

154 Criterios para la calificación de la iliquidez de la empresa y señales de alerta en PÉrez/MarTÍNEZ (2015) 102 - 116.

155 SANdoval (2014) 256, establece que nuestra legislación ha adoptado la teoría del estado de cesación de pagos para la regulación de las acciones revocatorias concursales. 
contratos se origina en beneficio del acreedor; requisito el cual, como pudimos ver, es del todo contraproducente para la contratación entre potenciales acreedores y una empresa determinada, futura deudora ${ }^{156}$.

Consideramos que la sola alusión al conocimiento del perjuicio por parte del acreedor, que en este artículo 288 no se presume, bastaría para estimar su mala fe, justificándose en este punto la subordinación de su crédito. Con ello se salvaría la contradicción a la que hacíamos referencia en aquellos casos en que, a pesar de existir perjuicio a la masa de acreedores -en los términos que en este trabajo se explican-, no sea posible revocar los actos y contratos, ni subordinar los créditos que para el acreedor se originen producto de la revocación, por no haberse podido determinar la mala fe del acreedor atendida la difícil y paradójica prueba que la ley exige respecto del conocimiento del mal estado de los negocios del deudor.

En tal sentido, ilustrativo es el ejemplo de la LCE, en la que de acuerdo al tenor literal de los artículos 71.1, 73.2 y 73.3, y según lo dicho respecto del artículo 71.2, se aprecia que si bien para el ejercicio de la rescisión concursal la mala fe del acreedor no tiene relevancia alguna ${ }^{157}$, al no exigirse como requisito de procedencia, para la subordinación de su crédito en virtud del artículo $92.6^{\circ}$ es necesario acreditarla. Al compararse la acción rescisoria concursal española con la acción rescisoria por fraude de acreedores del artículo 1291 del Código Civil espańol, en la que a nuestro juicio se encuentra su antecedente, independiente de considerarse si respecto del deudor debe o no concurrir el elemento subjetivo de intención de dañar a los acreedores ${ }^{158}$, en lo que respecta a la actividad

156 Al parecer, una configuración de las acciones revocatorias concursales más objetiva es a la que apela BAEZA (2013) 754 a 757.

157 Linacero (2005) 252, expresa que "Sin embargo, en la acción rescisoria concursal, el adquirente directo ("tercero inmediato"), quedará afectado por aquellas, ya sea un adquiriente a título oneroso o gratuito, ya sea de buena o mala fe. [...]

> > Lo anterior es consecuencia del fundamento de la acción rescisoria en el nuevo Derecho Concursal, al prescindir de la intención fraudulenta de los negocios realizados por el deudor en el periodo sospechoso, exigiendo únicamente el perjuicio patrimonial para la masa activa".

158 Según la doctrina y jurisprudencia actual no sería necesario, tal como lo expresa la Sentencia del Tribunal Supremo de España, de 26 de febrero de 2012, 7155/2012, fundamento jurídico cuarto, y las sentencias citadas en la misma. En el mismo sentido De Torres Perea, Juan Manuel (2001) Presupuesto de la acción rescisoria. Valencia: Editorial Tirant lo Blanch, pp. 415 a 419, al señalar en p. 416 que "la rescisoria ha ido abriendo paso a una nueva línea jurisprudencial que resta importancia al fraude, dado que no es suficiente proteger a acreedores frente a aquellos deudores dolosos movidos por el ánimo de perjudicar, sino también frente a aquellos otros que, eludiendo la responsabilidad que comporta la posición de deudor, no observan la prudencia i cuidado necesarios en su actividad patrimoniales. Más aún, la doctrina mas reciente ha llegado a señalar que el fraude en el deudor ha de inducirse e incluso identificarse con la evidencia del daño provocado por la insolvencia”. 
del acreedor, en la rescisión por fraude a los acreedores del Código Civil español la necesidad de que esté presente la mala fe, o ausencia de buena fe, es un requisito de procedencia. En efecto, respecto de esta acción es necesario, no que el acreedor tenga la intención de dañar, pero sí que tenga conocimiento del perjuicio que causa, que es donde precisamente encontramos la ausencia de buena $\mathrm{fe}^{159}$. De ello se deriva la necesidad de acreditar ausencia de buena fe respecto del acreedor para que la acción del artículo 1291 del Código Civil español fructifere.

Aplicando estos presupuestos a la rescisión concursal española, deberíamos decir que sería necesario acreditar la ausencia de buena fe en el acreedor para que la administración concursal, o en su defecto, los acreedores en su caso, puedan rescindir el acto.

Sin embargo, las normas de los art. 71.1, 73.2 y 3, 92.6 $6^{\circ}$, excluyen la necesidad de acreditar la ausencia de buena fe del acreedor para el ejercicio de la rescisión concursal, siendo solamente necesario acreditar el perjuicio para la masa activa que produce un acto celebrado dentro de los dos años anteriores a la declaración del concurso. En efecto, el artículo 71.1 permite ejercitar la acción sin necesidad de acreditar intención fraudulenta ni exigiendo mala fe en el acreedor ${ }^{160}$; el artículo 73.2 y 3 habla de los efectos de la rescisión cuando no ha habido, o ha habido, mala fe en quien contrató con el deudor; mientras que el artículo 92.6 solo califica de subordinado el crédito generado con la rescisión, en atención al art. 93.2 y 3 , cuando ha habido mala fe.

Se aprecia que la normativa española no exige que se esté en presencia de un acreedor de mala fe para la procedencia de la rescisión concursal, no obstante, siempre que se pretenda subordinar el crédito -originado por los efectos de tal rescisión-, requerirá la prueba de su mala fe.

En cuanto nos interesa, como podemos apreciar, la clave está en que la prueba de la mala fe del acreedor para efectos de estimar subordinado su crédito dice relación con el conocimiento que él mismo tenía o podía tener respecto del perjuicio para la masa activa, toda vez que este es el requisito que exige de forma principal LCE en su artículo 71.1 para la

159 De Torres (2011) 424, para quien "El estudio de este artículo [art. 1295 CC] nos obliga a considerar que en el tercero adquirente, el requisito subjetivo se manifiesta no en forma de fraude sino de ausencia de buena fe...", señalando a continuación en p. 425 que “... [mala fe], que equivale a la consciencia tenida por el adquirente de las consecuencias de su acto, es decir, a su ausencia de buena fe"...

160 SANCHo (2012) 1146. En cualquier caso, el legislador ha querido excluir expresamente la exigencia de un elemento subjetivo para el ejercicio de esta acción. o es necesario ni la intención fraudulenta del deudor al realizar el acto ni el consilium fraudis de quienes negocian con él. 
recisión concursal de los actos o contratos. La norma no hace mención alguna, señala la doctrina, a un requisito subjetivo.

Lamentablemente nuestra normativa incorpora este requisito en el artículo 288, el cual como tuvimos oportunidad de ver, contrariando el espíritu de la Ley No 20.720, representa un grave problema de incertidumbre entre los acreedores que pretendan contratar con un deudor, significando un evidente desincentivo a la contratación, y que repercute claramente en el comercio y el mercado.

\section{BibLIOGRAFÍA}

Alcover Grau, G (2003) "Aproximación al régimen jurídico de la reintegración concursal”. En García Villaverde, R., Alonso Ureba, A., Pulgar Ezquerra, J. (directores): Derecho Concursal. Estudio sistemático de la Ley 22/2003 y de la Ley 8/2003, para la reforma concursal. Madrid; Editorial Dilex, pp. 325 - 356.

Alemany, Jesús (2004) "Subordinación contractual y subordinación concursal". Revista española de de doctrina, jurisprudencia y bibliografía, No 2, pp. 1884 - 1901.

Alessandri, Arturo y Somarriva, Manuel (2011) Tratado de derecho civil. Parte preliminar y general. Santiago: Editorial Jurídica de Chile, tomo I.

Alessandri, Arturo; Somarriva, Manuel; y Vodanovic, Antonio (1990) Derecho Civil. Parte preliminar y parte general. 5a edición. Editorial Ediar ConoSur Ltda., tomo I.

Alessandri, Arturo; Somarriva, Manuel; y Vodanovic, Antonio (2009) Tratado de los derechos reales. Santiago: Editorial Jurídica de Chile.

Alferillo, Pascual (2011) "La mala fe". En: Universitas, No 122, pp. 442 $-482$.

Alonso Ledesma, Carmen (2004) “Comentarios". En Pulgar Ezquerra, Juana, Alonso Ureba, Alberto, Alonso Ledesma, Carmen y Alcover Grau, Guillermo (Directores): Comentarios a la legislación concursal. Editorial Dikinson, tomo I.

Aznar Giner, Eduardo (2013) La acción rescisoria concursal. Doctrina, jurisprudencia y formularios. Valencia: Editorial Tirant lo Blanch.

Baeza Ovalle, Gonzalo (2013) Derecho concursal chileno. Legislación vigente y reforma proyectada, $1^{\text {a }}$ edición. Editorial Thomson Reuters.

BANFi Del Río, Cristian (2012) "Breve revisión de la responsabilidad por interferencia de contratos del competidor en Chile". Revista Chilena de Derecho Privado, No 19, diciembre, pp. 165 - 192.

Barros Bourie, Enrique (2010) Tratado de responsabilidad extracontractual. Santiago: Editorial Jurídica de Chile. 
Boetsch, Cristián (2011) La buena fe contractual. Santiago: Editorial Jurídica de Chile.

Claro Solar, Luis (1932) Explicaciones de Derecho Civil chileno y Comparado. Editorial Imprenta Cervantes, tomo VII.

Contador Rosales, Nelson y Palacios Vargas, Cristián (2015) Procedimientos concursales. Santiago: Editorial Thomson Reuters.

Contreras Strauch, Osvaldo (2010) Insolvencia y quiebra. Santiago: Editorial Jurídica de Chile.

De Torres Perea, Juan Manuel (2001) Presupuesto de la acción rescisoria. Valencia: Editorial Tirant lo Blanch.

Diez Soto, Carlos (2006) Concurrencia y prelación de créditos: teoría general. Espańa: Editorial Reus.

EsCribano Gámir, Rosario (2005) "La reintegración de la masa activa del concurso". En Acedo, José et al.: Estudios sobre la Ley Concursal. Libro Homenaje a Manuel Olivencia. Madrid: Editorial Marcial Pons, tomo IV. pp. 4007 - 4044.

Espigares Huete, José Carlos (2011) La acción rescisoria concursal. Pamplona: Editorial Thomson Reuters.

Fernández Seijo, José María (2013) Los efectos de la declaración de concurso sobre los contratos. Barcelona: Editorial Bosch.

Ferré Falcón, Juan (2006) Los créditos subordinados. 1a edición. Navarra: Editorial Thomson Civitas.

García SAnz, Arturo (2005) "Notas sobre el sistema de reintegración de la masa en la nueva Ley Concursal. En Acedo, José et al.: Estudios sobre la Ley Concursal. Libro Homenaje a Manuel Olivencia. Madrid: Editorial Marcial Pons, tomo IV, pp-4063 -4082.

García-Cruces, José (2009) "Presupuesto y finalidad de la acción de reintegración en el concurso de acreedores”. En García-Cruces, José (director): La reintegración en el concurso de acreedores. Navarra: Editorial Aranzadi, Cizur Menor.

Garrido, José María (2004) "La subordinación de créditos". En Rojo, Angel y Beltrán, Emilio (directores): Comentario de la Ley Concursal. Editorial Thomson Civitas, tomo I, pp.1659 - 1668.

Goldenberg Serrano, Juan Luis (2010) "Consideraciones críticas respecto al denominado principio de la par conditio creditorum". Revista Chilena de Derecho, Vol. 37, No 1, pp. 73 - 98.

Goldenberg Serrano, Juan Luis (2012) "El problema temporal del inicio de los procedimientos concursales". Revista Ius et Praxis, año 18, No 1 , pp. 315-346.

Goldenberg Serrano, Juan Luis (2015) "Los créditos legalmente pospuestos en la Ley 20.720". Revista de Derecho, Vol. XXVIII, No 2, diciembre, pp. $91-116$.

Gómez, Rafael y Eyzaguirre, Gonzalo (2010) El derecho de quiebras. Santiago: Editorial Jurídica de Chile. 
Guillón, Antonio (2005) "La acción rescisoria concursal". En Acedo, José et al.: Estudios sobre la Ley Concursal. Libro Homenaje a Manuel Olivencia. Madrid: Editorial Marcial Pons, tomo IV.

Hidalgo, Pedro (2006) "La inexcusabilidad de la ignorancia de la ley: un principio, una presunción o una ficción". Revista de Derecho de la Universidad de Concepción, No 119-120, enero-diciembre, pp. 173186.

Larraín Ríos, Hernán (2003) Teoría general de las obligaciones. Editorial LexisNexis.

LinaCero de la Fuente, María (2005) Las acciones de reintegración en la Ley Concursal. España: Editorial Reus.

Martínez Reyes, María de los Ángeles (2012) “El perjuicio como fundamento de la acción rescisoria concursal". Revista de Derecho Concursal y Paraconcursal, No 12, pp. 167 - 196.

Massaguer, José (2014) "La rescisión concursal. Aspectos sustantivos". En Quetglas, Rafael y Veiga Copo, Abel (Directores): Problemas actuales del concurso de acreedores. Navarra: Editorial Thomson Reuters.

Palao Uceda, Juan (2013) La insolvencia inminente y el sistema concursal preventivo. Barcelona: Editorial Bosch.

Pérez Benítez, Jacinto (2012) "Créditos subordinados tras la reforma de la ley Concursal operada por la Ley 38/2011, de 10 de octubre”. En Prendes, P. y Muñoz Paredes, A. (directores): Tratado Judicial de la insolvencia. Editorial Cizur Menor, tomo II.

Pérez Benítez, Jacinto (2013) "Perjuicio patrimonial, interés de grupo y rescisión de garantías otorgadas en la financiación de grupos de sociedades". Revista de Derecho Concursal y Paraconcursal, No 19, pp. $155-164$.

Pérez Ragone, Álvaro y Martínez Benavidez, Patricio (2015) "Del sobreendeudamiento a la insolvencia: fases de crisis del deudor desde el derecho comparado europeo". Revista Chilena de Derecho, Vol. 42, No 1, pp. 93-121.

Puga Vial, Juan (2014) Derecho concursal. Del procedimiento concursal de liquidación. Ley 20.720. 4a edición actualizada. Santiago: Editorial Jurídica de Chile.

Pulgar Ezquerra, Juana (2005) La declaración del concurso de acreedores. Madrid: Editorial La Ley.

Quetglas, Rafael Sebastián (2013) Concurso y rescisión. Valencia: Editorial Tirant lo Blanch.

Rodríguez Lazo, Carlos (1937) Sintesis de la teoría general de las obligaciones. Editorial Nascimento.

Rojo, Angel (2004) "Comentarios". En Campuzano, Ana Belén (Coordinadora): Comentarios a la Ley Concursal. Madrid: Editorial Thomson Civitas, tomo II. 
Román Rodríguez, Juan Pablo (2001) Salvamento de empresas en crisis. Santiago: Editorial Jurídica de Chile.

Sancho Gargallo, Ignacio (2012) "Las acciones de reintegración”. En Prendes Carril, Pedro y Muñoz Paredes, Alfonso (directores): Tratado judicial de la insolvencia. Navarra: Editorial Aranzadi, tomo I.

Sandoval López, Eduardo (2014) Reorganización y liquidación de empresas y personas. Derecho concursal. $7^{\text {a }}$ edición actualizada. Santiago: Editorial Jurídica de Chile.

Sandoval López, Ricardo (2007) La Insolvencia de la empresa. Derecho Concursal: quiebra, convenio y cesión de bienes. 6a edición. Santiago: Editorial Jurídica de Chile, tomo VI.

Trujillo, Iván (2003) El sobreendeudamiento de los consumidores. Disponible en: http://www.ecri.eu/new/system/ files/13+Sobreendeudamiento-spanish-Trujillo.pdf [Fecha de visita 13 de enero de 2016], pp. 1 - 167.

Veiga Copo, Abel (2006) "Los créditos subordinados en la Ley Concursal'. Revista de Derecho Bancario y Bursátil, No 102, abriljunio. Disponible en: http://www.icab.cat/files/242-148050DOCUMENTO/bVeiga2.pdf [Fecha de visita 10 de diciembre de 2015], pp. 9 - 69.

\section{NORMAS JURÍDICAS}

Boletín No 8324-03 del Senado, Proyecto de Ley que sustituye el régimen concursal vigente por una ley de reorganización y liquidación de empresas y personas, y perfecciona el rol de la Superintendencia del ramo, 23 de mayo de 2012.

Historia de la Ley No 20.720, que sustituye el régimen concursal vigente por una ley de reorganización y liquidación de empresas y personas, y perfecciona el rol de la Superintendencia del ramo. Biblioteca del Congreso Nacional. Disponible en: http://www.bcn. cl/historiadelaley/nc/historia-de-la-ley/4343/

Ley No 20.720, sustituye el régimen concursal vigente por una ley de Reorganización y Liquidación de Empresas y Personas, y perfecciona el rol de la Superintendencia del ramo. Diario Oficial, 9 de enero de 2014

Ley No 18.175, fija nuevo texto de la Ley de Quiebras. Diario Oficial, 28 de octubre de 1982

Ley 22/2003, de 9 de julio, Concursal. Boletín Oficial del Estado, No 164, de 20 de julio de 2003 
Real Decreto Legislativo 1/2010, de 2 de julio, por el que se aprueba el texto refundido de la Ley de Sociedades de Capital. Boletín Oficial del Estado, No 161, de 3 de julio de 2010.

\section{JURISPRUDENCIA}

Sentencia del Tribunal Supremo 7155/2012, de 26 de febrero de 2012.

Sentencia del Tribunal Supremo 7265/2012, de 26 de octubre de 2012.

Sentencia del Tribunal Supremo 8314/2012, de 7 de diciembre de 2012 